\title{
Time after time: party organizational strength in new and old democracies
}

\author{
Pedro Floriano Ribeiro ${ }^{1}$ (D)
}

Luis Locatelli²

\begin{abstract}
The 'time factor' has not been systematically considered in cross-national studies on party organizations. Relying on the largest dataset to date on party organizations, namely the Political Party Database Project (PPDB), the article tests the impact of time as a two-level variable (duration of democracy and age of parties) on parties' organizational strength in new and established democracies. We add original data from three Latin American countries to the nineteen countries covered by the first PPDB database (132 parties overall). The results suggest that parties in established democracies have less members and more money than those of newer democracies. Among the latter, the greater capacity for mass mobilization produces stronger parties-as in Latin America-compared to the Eastern European countries. The findings challenge the traditional view of the exceptional weakness of Latin American parties and point to the importance of time as a multilevel variable: besides the national context, the "ancestral" party origin in previous regimes have a large impact on organizational strength.
\end{abstract}

Keywords: party organizations; political parties; party membership; party finance; Latin America

\section{Introduction ${ }^{3}$}

Many studies in political science consider time as a relevant factor in the explanation of political processes, implicitly or explicitly, when adopting historical approaches. However, a few authors have systematically placed "politics in time" (Pierson, 2004). In this sense, the influence of time as a multilevel variable-duration of democracy and age of parties-on party membership, party funding, and organizational strength has not been systematically tested until today in cross-national comparative studies. This is

\footnotetext{
1 Universidade Federal de São Carlos. São Carlos (SP), Brazil. E-mail: <pfribeiro@ufscar.br>.

2 Fundação Getúlio Vargas. São Paulo (SP), Brazil. E-mail: <luis.locatelli@fgv.edu.br>.

3 Previous versions of this article were presented at the 113th APSA Annual Meeting (San Francisco, CA, September 2017) and at the University of São Paulo (Department of Political Science, May 2017). We would like to thank the participants of these panels for their comments, especially Susan Scarrow, Alexander Tan, Fernando Limongi, and Paolo Ricci. The authors thank Susan Scarrow for sharing information about some of the procedures used in the PPDB Project. The research was supported by the Sao Paulo Research Foundation (FAPESP, Grants 12/05132-0 and 17/12222-9). We also thank the American Political Science Association, which awarded a Travel Grant for attendance at the 113th APSA Annual Meeting. For replication data, see <https://www. politicalpartydb.org/>; and <https://www.projectmapp.eu/>. The usual disclaimer applies.
} 
quite surprising, considering that the time and conditions of party existence are essential elements in the processes of party institutionalization (Panebianco, 1988; Casal Bértoa, 2017). While organizational strength and party institutionalization are empirically and conceptually distinguishable, we should expect-relying on the literature on the latter-the time component to be an important factor behind organizational strength (Harmel and Janda, 1994; Dix, 1992; Harmel, Svasand, and Mjelde, 2016).

On the other hand, there is still a gap in comparative and systematic analyses on party organizations in new democracies, with the lack of solid empirical basis (longitudinal and cross-national data), notably about Latin American and Asian parties. In Latin America, contemporary research on parties focuses mostly on the party system level, especially regarding the issue of institutionalization (Carreras, 2012; Mainwaring, 2018). Analyses on political parties are mostly case-oriented, centered on specific countries, parties or dimensions, and party organizations are still "black boxes" in the region (Levitsky, 2001).

In one of the pioneering studies about Latin American parties, Dix (1992) argued that the parties of the new third-wave regimes presented some signs of greater institutionalization compared to the generation prior to the coups d'état of the 1960 s and 1970s. Since then, however, little progress has been made in systematically measuring the strength of political parties in the region with broad cross-national perspectives ${ }^{4}$. Despite that, and despite Dix's optimistic evaluation, the literature has taken for granted that Latin American parties are still organizationally weak (Mainwaring and Shugart, 1997; Levitsky et al., 2016, p. 1-3). However, one question was never clearly answered: to what are they "weak" in comparison?

Following Sartori's (1970, p. 1.035) admonishment that "to compare is to control," this article tests the influence of time on party organizational strength and performs an objective 'proof of the pudding' about party strength in Latin America. Assuming that it takes time to build strong organizations (Panebianco, 1988; Tavits, 2013), we ask: are the parties in newer democracies weaker than the parties in established democracies? Are there substantial differences between the parties in Latin America and in other regions? After controlling for the national level (duration of democracy), would the time variable have a substantial impact on organizational strength also at the party level-hence "time after time"? These research questions are answered by using strategies and indicators that can 'travel' in cross-national and cross-regional comparisons, developed by the Political Party Database Project (PPDB) (Scarrow, Webb, and Poguntke, 2017). We add original data from three Latin American cases (twenty parties) to the nineteen countries covered by the first round of data released by the PPDB (Poguntke, Scarrow, and Webb, 2017). Of course, Brazil, Chile, and Mexico are not representative of all the Latin American party systems. However, they may be the most consolidated systems in the region (Mainwaring, 2018), and this is a first attempt to move beyond the 'usual suspects' and to include Latin

\footnotetext{
${ }^{4}$ For some studies on comparative party organizations, see Alcántara Sáez and Freidenberg (2001), Alcántara Sáez (2004), Harmel and Taylor-Robinson (2007), Webb and White (2007), Wills-Otero (2009; 2014), Ponce (2013), Došek (2014), Levitsky et al. (2016), and Lupu (2016).
} 
America in a comparative cross-regional study on party organizations, which justifies the selection of three cases for which we have more reliable data. In order to expand the coverage towards quite different contexts, we need to rely on less demanding empirical indicators and data-a trade-off faced by all the scholars studying comparative party organizations (Janda, 1980; Katz and Mair, 1992; Scarrow, Webb, and Poguntke, 2017). Therefore, the data on party membership and finance, for the period 2011-2014, are summarized in a simple additive index: the Party Strength Index (PSI) (Webb and Keith, 2017). Overall, we rely on a database with 132 parties in 22 countries, covering third-wave democracies, post-communist countries and advanced democracies. By doing this, we resume the tradition of a "most different" approach to party comparative analyses (Janda, 1980), with both cross-national and cross-regional perspectives.

This article has two components, one rather descriptive and the other more explanatory. The purpose in the descriptive approach is to expand the coverage of comparative research on party organizations towards Latin America. We do that by gathering and presenting original data on the three indicators separately (party membership, party funding, and party strength), with aggregations by country, region, and new and old democracies and by party families in Latin America. With simple exploratory techniques (correlations and tests of mean differences), some inferences are already possible even in this descriptive component. In the multilevel explanatory dimension, contextual factors (region, duration of democracy, and socioeconomic control variables), as well as party-level variables (origins and time of existence of each party), are included in multivariate models to explain the differences between parties in terms of membership, funding, and strength. In both components, we test three specific hypotheses that rely on previous findings about party membership, party finance, and organizational strength.

As emphasized by Bartolini and Mair (2001, p. 327), "any discussion of the role and importance of political parties in new or developing democracies is unlikely to ensue without reference to their role and importance in the more established democracies." More recently, Webb, Poguntke, and Scarrow (2017, p. 317-318) argued that it is time to "move the field beyond its traditional heartland in most-similar-system comparative studies of practices in parliamentary regimes. As the ranks of long-term presidential democracies grow, it seems theoretically indefensible to exclude Latin American, Asian and African regimes from cross-national comparative studies of party organization." Based on systematic empirical indicators, we are better able to test the relative strength of Latin American parties using both cross-national and cross-regional approaches, moving from a perspective rooted in ideal type models (as Duverger's mass party) to one rooted in specific indicators and dimensions.

With those considerations in mind, the article proceeds as follows. The next section briefly discusses the concepts and measures of party strength and the efforts for broad comparative research on party organizations as well as presents the hypotheses. The 
following section introduces the cases, data, and research design. The section 'Findings' presents the data on party membership, party income, and party strength and tests the hypotheses. In the final two sections, we evaluate the hypotheses and discuss the results. The findings show that parties in established democracies have less members and more money than those of newer democracies. However, much of the variation can be explained by the level of socioeconomic development and the parties' historical origins: traditional democracies are richer (and so are their parties) and have older parties than new democracies. Among the newer democracies, mass mobilization partially compensates for the lack of money in Latin American parties. Overall, time proved to be a strong predictor of party strength, and more significant at the party than at the national (systemic) level. The "ancestral" party origin in previous regimes has a large impact on the organizational strength, larger than the impact of duration of democracy or the impact of party age in the current system. The findings challenge assumptions about the exceptional weakness of Latin American party organizations and open several avenues for further research.

\section{Party strength in new democracies}

Why should we care about party organizational strength? Strong parties are especially important for new democracies (Van Biezen, 2003; Tavits, 2012) and for the institutionalization of party systems (Mainwaring and Torcal, 2006). Strong parties are more resilient and adaptable to environmental challenges than weak parties, and they are better able to generate stability in the structure of competition: they offer information shortcuts to voters and are more efficient at attracting and sustaining their support over time. Stronger parties are also more effective in formulating policy and are more accountable, since they facilitate the clarity of responsibility (Tavits, 2012, p. 84-85; Lupu, 2016).

The most recent survey data show that about a third of Latin American voters have party linkages-a surprising figure given the low levels of institutionalization of party systems in the region. There is great variation across countries, from $14 \%$ of party ID in Chile to $61 \%$ in the Dominican Republic; Mexico and Brazil have $30 \%$ and $28 \%$ of party ID respectively (Nadeau et al., 2017, p. 69) ${ }^{5}$. These figures are similar to those found in other newer democracies, such as Poland (27\%), the Czech Republic (31\%), and Hungary $(44 \%)$; however, they are below those found in third-wave developed countries, such as Portugal $(61 \%)$ and Spain $(55 \%)^{6}$.

Party identification figures as the most significant explanatory variable for voting behavior in several of the recent studies about Latin America (ahead of sociodemographic factors and left-right self-placement), consistent over time and across all countries (Carreras and Castañeda-Angarita, 2014; Carlin, Singer and Zechmeister, 2015; Nadeau

\footnotetext{
5 Data from the Americas Barometer (LAPOP: Latin American Public Opinion Project), with surveys carried out between 2008 and 2012. See Carlin, Singer and Zechmeister (2015) and Nadeau et al. (2017).

${ }^{6}$ European Social Survey, 2014.
} 
et al., 2017). Partisanship in the region is correlated with age, civic engagement, belief in the efficacy of political action, and access to information, which form a profile quite similar to that of advanced democracies (Lupu, 2015).

However, although party identification has been an important measure of citizens' attitudes towards political parties, party organizations are not reducible to the perceptions and behavior of voters and political elites (Panebianco, 1988; Cotter et al., 1989, p. 5-6). Party membership, party funding, and other objective dimensions of party organizations are still understudied subjects in the region (Levitsky, 2001). One reason for that is the difficulty in gathering data. Data on party membership in Latin America vary widely in terms of reliability, and countries with stronger and more independent electoral bodies (such as the three cases presented here) have better and more systematized information. These official records show high levels of heterogeneity across the countries in the region, from about $6 \%$ of national membership (members/electorate ratio) in Peru and Chile to $60 \%$ in Panama (Došek, 2014). Regarding party funding, the predominant model in the region is mixed: parties have access to both public and private resources. Latin American parties are, in general, strictly regulated by the state, and these regulations have expanded to the supervision of intraparty finances. The progressive empowerment of control mechanisms in some countries has made it more feasible to use official records about party membership and finance to assess the party strength in the region (Molenaar, 2017; Londoño and Zovatto, 2014) 7 .

There is no consensus on the dimensions and indicators to measure party organizational strength (Tavits, 2013, p. 16). The more specific and empirical-oriented literature on the subject took its first steps in the $1980 \mathrm{~s}$, evaluating the impact of organizational strength on other variables such as electoral success and legislative behavior (Gibson et al., 1983; Coleman, 1996; Cotter et al., 1989; Tavits, 2013). In a pioneering effort, Gibson et al. (1983) suggest a concept of organizational strength around two dimensions: organizational complexity (bureaucratization) and programmatic capacity (voter support). Subsequent cross-national analyses have listed some alternative dimensions to measure party strength and to test its impact over other political outcomes and processes (see Janda, 1983; Janda and Colman, 1998).

In analyzing the parties in four post-communist countries, Tavits $(2012,2013)$ employs three dimensions to measure organizational strength: 1) professionalization of the central organization (staff size); 2) territorial extensiveness (local presence); and 3) membership size and activism. She points out that the parties are not homogeneous in terms of the investment made in their organizations, even in the face of similar institutional and social settings (Tavits, 2013, p. 197). The environment is relevant, but not determinant to understand the organizational capabilities - which confirms findings about advanced democracies (Harmel and Janda, 1994; Gauja, 2017; Scarrow, Webb, and

\footnotetext{
7 For instance: "(...) the Mexican Instituto Nacional Electoral (National Electoral Institute - INE) constitutes one of the largest, most powerful, and well-funded electoral monitoring bodies in the world" (Molenaar, 2017, p. 31).
} 
Poguntke, 2017). Stronger organizations achieve better electoral results and have a more cohesive legislative behavior (Tavits, 2012; 2013). Challenging the recurring diagnosis about the general weakness of party organizations in new democracies, Tavits (2012, 2013) concludes that this dimension is an important explanatory factor in their respective national contexts.

The "time factor" is the most common dimension used to explain differences between parties in terms of party strength and (mainly) party institutionalization-not always in a systematic way though (Janda, 1980; Panebianco, 1988; Dix, 1992; Harmel and Janda, 1994; Mainwaring and Scully, 1995). For the purpose of this analysis, we argue that the "time factor" is a multilevel variable and must be conceptualized and measured systematically, in both contextual (national) and party levels. In theoretical terms, this approach is based on Panebianco's (1988) concept that variations in party organizations usually respond to two major (and non-excluding) factors: (1) party elites make important organizational choices based on a "bounded rationality," limited by the perceptions about the environment; (2) similarly to a biological organism, party organizations usually assume several conformations in each stage of their development (or lifetime), in face of different life-cycle dilemmas (see also Harmel and Janda, 1994, p. 262).

At the contextual level, a long period of stable and competitive democracy encourages party elites and party members to invest resources (money, labor, time etc.) in the party organization building. Therefore, we should expect that duration of democracy and institutional stability to be important factors that strengthen party organizations (Harmel and Janda, 1994). At the party level, the "party age" is the indicator most commonly associated with party institutionalization, "an objectively established survival record" (Harmel, Svasand, and Mjelde, 2016, p. 7). It takes time to stabilize procedures and routines, to build party attachments, to develop autonomous bureaucracies, and to expand the territorial presence of party organizations (Dix, 1992; Van Biezen, 2003; Tavits, 2013, p. 8-9). In Latin America, party age is also associated with higher levels of mass mobilization and stronger societal roots (Mainwaring and Scully, 1995, p. 15).

In short, the party age has been considered a proxy for party institutionalization (Casal Bértoa, 2017, p. 419), chiefly when other indicators and data are not available in large- $\mathrm{N}$ cross-national studies. Nevertheless, the empirical connections between time and party strength have remained virtually unexplored until now (Harmel and Janda, 1994; Dix, 1992; Harmel, Svasand, and Mjelde, 2016).

\section{The PPDB Project}

The debate on party organizational strength has not always been linked to the broad collaborative efforts that have tried to gather cross-national data on party organizations. Among the pioneering comparative research on the subject, adopting both cross-party and cross-national perspectives, Kenneth Janda's (1980) study-which covered 
158 parties in 53 countries-stands out, followed by a few others such as Von Beyme's (1985), Ware's (1987), and Katz and Mair's respective works (1992).

As noted by Janda $(1980 ; 1983$, p. 171) and Ware (2011), the few efforts in broad comparative research on party organizations have always suffered from the low standardization of concepts and indicators and the tendency for parochialism. According to Janda (1980, p. XIII)

The dominant tradition within comparative politics has been overly conservative. Students have been cautioned to limit their comparisons to "things that are similar" rather than to things that are "different." (...) Instead of promoting the integration and synthesis of knowledge, comparative parties research tended toward channelization within cultural-geographical areas. (...) Latin American scholars treated parties in their countries as sui generis. While detailed studies of "similar" parties capitalized on the researchers' expert knowledge of domestic politics in certain countries, the price paid for descriptive accuracy was narrowness of conceptualization. (...) We must study parties where they are weak as well as where they are strong.

The Political Party Database Project (PPDB) is an important step to overcome these difficulties. Its main purpose is to compare party organizations based on middle-level theorizing and hypotheses, around three dimensions: 1) structures and distribution of internal influence; 2) human and financial resources; 3) representative strategies, linkages, and participation regarding groups and individuals. The project expands the coverage of this type of study towards recent democracies and follows a comparative and empirically oriented approach. Its main concepts recover dimensions of previous studies on party organizations. However, there is no rigid or predefined interaction between those dimensions (Scarrow and Webb, 2017, p. 6-7). In this sense, the dimensions encompass various types of parties, with different origins, rules, resources, internal practices, and environmental contexts. A crucial advantage of the project's framework is moving from ideal types and evolutionary models to dimension-oriented analysis, presenting a common conceptual vocabulary that can "travel" to other regions and institutional settings-for example, to the presidential regimes that prevail in Latin America (Poguntke, Scarrow, and Webb, 2016; Scarrow, Webb, and Poguntke, 2017).

In addition, this cross-national research provides a specific indicator for measuring organizational strength. As is often the case in large-N comparative studies, the use of a relatively simple composite index-the Party Strength Index (Webb and Keith, 2017)inevitably entails some loss of particularities (number of attributes); however, it guarantees a significant improvement in extension, generalization, and explanatory power (external validity).

Relying on previous findings about party membership, party finance, and organizational strength, in the next sections we test three hypotheses: 
- $\quad \mathrm{H} 1$ - It takes time to develop strong party organizations. At the national level, we expect that parties in established democracies will be stronger than those in newer ones: the duration of the democratic regime (expressed in years) will have a positive impact on party organizations.

- $\quad \mathrm{H} 2$ - Newer democracies are not homogeneously strong or weak in terms of party organizations. At the regional level, we should find that parties are stronger in the three Latin American cases when compared to Eastern European cases due to the totalitarian legacy of post-communist countries, which prevent parties from recruiting large contingents of members (Van Biezen, 2003; Ponce and Scarrow, 2016) $)^{8}$.

- H3 - At the party level, it is worth noting that there are new parties in old democracies, and old parties in recently democratized countries ${ }^{9}$. The party's first appearance (what we call here party origin) can be prior to the recent democratization (e.g. the PRI in Mexico, the PSOE in Spain, or the PMDB in Brazil). After controlling for the duration of democracy and other contextual variables, we expect that the party age (foundation) and the party origin (both expressed in years) will have a positive impact on the party strength.

With an exploratory approach, we also test if left-wing parties in Latin America are organizationally stronger than conservative/right-wing parties, reproducing the pattern found in other regions, particularly in the Western European democracies (Webb and Keith, 2017).

\section{Cases and data}

The first round of the PPDB dataset (round 1a, released in 2017) covers five new and stable democracies (Portugal, Spain, Czech Republic, Hungary, and Poland) and 14 established democracies (Australia, Austria, Belgium, Canada, Denmark, France, Germany, Ireland, Israel, Italy, Netherlands, Norway, Sweden, and the United Kingdom $)^{10}$. In order to expand the dataset to Latin America, we included data about twenty parties from Brazil, Chile, and Mexico. The three countries are covered by the PPDB project; however, their data were not included in the project's round 1a dataset. Therefore, we gathered the data used here ourselves. The final dataset, with the inclusion of the Latin American parties, comprises 132 parties in 22 countries.

Chile, Brazil, and Mexico are stable democracies with wide variation in terms of democratic trajectory and party system institutionalization since the early 1990s. Chile

\footnotetext{
8 There are differences between authoritarian and totalitarian legacies. According to Van Biezen (2003, p. 115): "Most parties attribute the lack of large memberships to the legacy of the past, the contention usually being that four decades of communism have given the political party a negative image among the public at large, which is said to discourage people from affiliating to, let alone participating actively in, such a party". ${ }^{9}$ We are grateful to Alexander Tan for calling the attention about this point.

10 See <http://www.politicalpartydb.org/>.
} 
was, and continues to be, one of the few cases of an institutionalized party system in the region. Brazil has experienced a gradual process of institutionalization since then, while Mexico only completed the regime transition as its party system became more open and institutionalized (Mainwaring, 2018).

The selection also follows pragmatic reasons: in contrast to the increasing availability of data from cross-national public opinion surveys, researchers still face enormous challenges in collecting reliable data on party membership and finance in the region (Došek, 2014; Londoño and Zovatto, 2014). Due to the efficiency of their electoral control bodies ${ }^{11}$, Brazil, Chile, and Mexico are the countries with the highest availability and reliability of data on party organizations in the region.

In order to undertake cross-national and cross-regional comparisons, expanding the coverage to Latin America, we followed the same research design used by the PPDB project (Scarrow, Webb, and Poguntke, 2017). Considering the effective number of parliamentary parties ${ }^{12}$, we selected ten parties in Brazil, five in Mexico and five in Chile: these are the major parties in each country, based on the results in the last two general elections (see the Appendix for a full list of parties by country). According to the six party families employed by the PPDB, and following the classification of the MAPP project ${ }^{13}$, two of the twenty Latin American parties can be classified as liberals, nine as Christian democrats/conservatives, and nine as social democrats, socialists, or greens. Because of the small number of cases in the first category (and considering that liberalism in Latin America is associated with right-wing policies and parties), we recoded the parties into two major blocs: center-left (social democrats/greens) and center-right (liberals and Christian democrats/conservatives).

For the analysis of the "time component," we also build on the database and the criteria of the MAPP project (Van Haute, Paulis, and Sierens, 2017). Two potentially different dates are considered for each party: (i) the date of foundation (or reorganization) in the current democratic regime (party age); and (ii) the date of origin (party origin), which refers to the initial appearance of the party, even with other names and/or in previous (including authoritarian) regimes. For the variable about the duration of current democratic regimes, we adapted the data from Cheibub, Gandhi, and Vreeland (2010).

We gathered official data on national party membership and the finance of national parties' head offices provided by the parties themselves or by the electoral control bodies. Both party membership and party income data are from the period 2011-2014 (the period covered by the PPDB), and we calculate the averages for each party and country (which stabilizes the oscillations and minimizes the noise in the figures) ${ }^{14}$. The party membership (official party members) is always controlled for the polity size, through the M/E ratio: total

\footnotetext{
11 Brazil: Superior Electoral Court, TSE; Mexico: National Electoral Institute, INE; and Chilean Electoral Service, Servel.

12 ENPP in Brazil = 13.2; Chile = 6.6; Mexico $=5.7$ (Gallagher, 2017).

13 Members and Activists of Political Parties. See <https://www.projectmapp.eu/>.

14 Party membership data are available at <www.projectmapp.eu/>.
} 
party membership as a percentage of the national electorate. The party income is expressed in Euros.

The Party Strength Index (PSI) is a quite straightforward composite index. It is calculated by adding the $z$ scores of two indicators: the M/E ratio and the party income / electorate ratio. As the $z$ scores are calculated based upon the mean and standard deviation of the whole sample, we re-calculated the $z$ scores for all 132 parties. Thus, the PSI scores presented in this article are slightly different from those found in Webb and Keith (2017) (see all the party scores on the Appendix, Table B).

Besides the relations hypothesized above at the national $(\mathrm{H} 1)$, regional $(\mathrm{H} 2)$, and party levels (H3), we cannot ignore that some contextual variables can also have an impact on the two dimensions that form the PSI (members and money). In the next sections, these dimensions are always controlled for the polity size (electorate), following the procedures of the PPDB (Webb and Keith, 2017). Additionally, it is reasonable to expect that wealthier countries have richer parties, and that party organizations can be more dependent on labor-intensive activities in the less developed countries (Norris, 2002; Tavits, 2013). Therefore, we use the socioeconomic development (GDP, GDP per capita and the Human Development Index) as control variables in the models.

One may still ask how much official data reported by parties to state organs are inflated and whether they can accurately indicate the participation of members within the parties. First, when we work with cross-national comparative research on party organizations, there is no better alternative: "(..) any figures, even if inflated or crudely estimated, are better than none" (Mair and Van Biezen, 2001, p. 8) ${ }^{15}$. In large- $\mathrm{N}$ comparative analyses, there are always problems with the data; however, they tend to be randomized, and should not impede one from finding patterns and associations between the variables. Questions can also arise about the importance of parties and party members in Latin America. As exposed in the previous section, the levels of partisanship in the region are significant, and the party attachment has influenced other political outcomes. Besides, the few studies on the subject have indicated that these are not fictitious members: there are active members in all the major parties of the region. The members' profiles are quite similar to those found in advanced democracies: compared to the general population, they are older and wealthier, more informed and more educated, and more sensitive to civic norms; they also have positive attitudes toward institutions and the efficacy of political action (Ponce, 2013; Došek, 2014; Ribeiro, 2014; Lupu, 2015; Speck, Braga and Costa, 2015).

\footnotetext{
15 "The choice for the analyst is therefore either to accept at more or less face value those figures that are made available by the party organizations (...); or simply to do without, and to accept that little meaningful work can be done on party memberships on a comprehensive cross-national basis. (...) in common with strategies adopted by previous researchers in this field, we have opted for the first alternative" (Mair and Van Biezen, 2001, p. 8).
} 


\section{The Latin American cases}

Chilean democracy was restored in 1990, after the defeat of Pinochet's dictatorship in the 1988 plebiscite. The country has a presidential and unitary state, with an asymmetric bicameralism. The Senate has strong legislative powers, but a reduced capacity to oversee the executive when compared to the lower house. As in other multiparty democracies, the distribution of cabinet positions among government parties is decisive in explaining the success of the executive branch. The 1980 Constitution increased presidential powers visà-vis the legislature, and the presidents have controlled the legislative process (Valenzuela, 1995; Angell, 2007).

Chile had a binomial electoral system until 2013: each district elected two senators and two deputies, and each citizen had only one vote. Parties or party coalitions could present lists with two candidates for each position (Valenzuela, 1995; Angell, 2007). This arrangement was replaced by a proportional system in 2015.

Chilean party system before Pinochet's regime was organized around structural cleavages-religion (Catholicism and secularism) and class. After the dictatorship, parties' positions in relation to the authoritarian legacy became an important issue. The major leftwing parties are the PS and the PPD, while the most important centrist party is the PDC. The three parties constituted the hard core of the center-left coalition that ran the country until 2010 (the Concertación). On the center-right, UDI and RN form the Alianza coalition (replaced by the current Chile Vamos), which won the presidency for the first time in 2010. In 2014, the new center-left coalition (Nueva Mayoría) regained the control-but lost again in 2017. Compared to other Latin American countries, Chilean party system is usually described as highly institutionalized, with relevant social anchorage (Valenzuela, 1995; Angell, 2007; Carreras, 2012).

Brazil's institutional setting was designed during the democratization process that started in the late 1970s, combining federalism, the presidential system, bicameralism, open-list proportional voting for legislatures, and a multiparty system. Seats in the lower house are distributed between parties or party coalitions, and the most voted candidates in each list are elected. The coexistence of several consensual elements (Lijphart, 1999) was considered problematic: the multiplication of veto players would lead the country to instability and institutional deadlocks (Ames, 2001). Nevertheless, Brazil was governable until the 2015 presidential crisis, and the party system has developed a significant degree of stability over the period (Mainwaring, 2018). As in Chile and Mexico, the president has extensive institutional mechanisms to induce cooperative behavior in the legislature. Parliamentary parties are more cohesive and disciplined than expected, and they have been central actors in Brazil's "coalition presidentialism" (Cheibub, Elkins, and Ginsburg, 2011; Raile, Pereira, and Power, 2011; Palermo, 2016).

Despite the extreme fragmentation of the party system in the legislature, a structure of competition organized around two blocs has been dominant in presidential 
races since 1994. The PT leads the center-left bloc, while the center-right bloc was led by the PSDB until 2014. The PMDB occupies a pivotal position in the system; along with other medium size right-wing parties, it forms a group that is willing to participate in any government coalition. The two Cardoso elections (PSDB, 1994 and 1998), the four PT wins (2002 and 2006 with Lula; 2010 and 2014 with Dilma Rousseff), and the dynamics in Congress between elections were structured around this pattern until recently (Limongi and Cortez, 2010; Melo and Câmara, 2012; Braga, Ribeiro and Amaral, 2016; Meneguello and Arquer, 2018). The PT-PSDB dynamic was broken in 2018 when a far-right candidate from a small party, Jair Bolsonaro, won the presidency.

For most of the twentieth century, Mexico was dominated by a single party (PRI): the country was classified as a "hegemonic party system in transition" (Mainwaring and Scully, 1995). The 1988 general election was the critical election for democratization, resulting in subsequent electoral reforms that progressively increased the proportional features of Mexico's electoral system. The country currently adopts a mixed system: 300 deputies are elected in uninominal districts, while 200 are chosen in a closed list PR system. Contrary to Brazil and Chile, Mexican rules do not allow the reelection for presidency and state governors, which strengthens the political parties (Palma, 2010).

The Congress was a rubber stamp of the executive until 1988. The decline of PRI, the electoral reforms, and the wins of opposition parties increased the powers of parliament since then. Nevertheless, the executive remains as the dominant actor in the system, as the president has wide legislative powers and also controls his party de facto (Palma, 2010; Cheibub, Elkins and Ginsburg, 2011). Mexico combines presidentialism, federalism and a multiparty system with three major parties: PRI, PAN, and the left-wing PRD. The PRI lost the presidency for the first time in 2000, to a center-right party, the PAN, which won again in 2006. The PRI would regain the presidency in 2012, with Enrique Peña Nieto. The 2018 general elections may represent an inflection point in this scenario. Manuel López Obrador, from the Morena (a party that is included in this study), beat the powerful machines of the PRI, PRD, and PAN, winning the presidential election.

Political parties are firmly regulated by state party laws in Chile, Mexico, and Brazil, and they are compelled to formalize their membership structures. In Brazil, only party members can become candidates; in Mexico and Chile, the requirements for party registration and functioning have been linked to a minimum threshold of membership (Molenaar, 2017). The three countries adopted a mixed system for political funding for most of their current democratic periods. In Chile and Brazil (until 2015 for the latter) ${ }^{16}$, parties and candidates can raise private funds from companies and individuals, while in Mexico only individuals can donate. In the three cases, the state guarantees parties and candidates free access to television and radio, through tax exemptions to broadcasting companies. Parties in those countries usually receive direct public funding in proportion to

16 At the end of 2015, the Brazilian Supreme Court banned all kinds of donations from companies; therefore, public resources have become more essential to all parties and candidates. 
the electoral performance (Molenaar, 2017; Ribeiro, 2013; Londoño and Zovatto, 2014). This dependency on public funding varies widely across the three countries. The state dependency is extreme for the Mexican parties, while Brazilian parties were close to the average of the countries included in the PPDB in the $2011-2014$ period (about $55 \%$ of public funding). In Chile, private funding prevails over public subsidies (Casal Bértoa et al., 2014; Londoño and Zovatto, 2014, p. 140; Poguntke, Scarrow, and Webb, 2016) ${ }^{17}$.

\section{Findings: members, money and party strength}

In Table 1 we present data on party membership, adding the three Latin American cases to the countries covered by PPDB round 1 a data (in descending order, according to the $M / E$ column) ${ }^{18}$. Confirming previous findings (Došek, 2014), membership figures are impressive in Latin America: only Austria has a national membership/electorate ratio (M/E) higher than those of Brazil and Mexico. Even with electorally weak parties among the twenty cases (e.g. less than $5 \%$ of votes in the last general election), the average M/E ratio per party is $1.24 \%$, well above the overall average $(0.67 \%)$, the average of PPDB round $1 \mathrm{a}$ parties $(0.58 \%)$, and the average of East European parties $(0.26 \%)$. Each Mexican party has almost two million members; each Brazilian party has around one million. The mean party membership tends to be higher in the eight newer democracies when compared to more traditional democracies. However, the new democracies can be divided in two groups: third-wave democracies (Latin America, Portugal, and Spain) and post-communist countries. As expected, party membership is below the average in the latter. Left-wing parties have a larger membership than conservative parties in the three Latin American cases-which is consistent with the traditions of party politics in the region (Ames and Power, 2007; Levitsky et al., 2016). Considering the main indicator (M/E ratio), all differences of means between the groups of countries are statistically significant (at the levels flagged in the Table 1$)^{19}$.

\footnotetext{
17 Brazil's figures: these are our own calculations, considering the ten parties included in this article.

18 Figures presented in Table 1 include only the 132 parties for which we have complete data for the calculation of the Party Strength Index. Moreover, some figures may vary across the studies that rely on PPDB data depending on the exact point in time of the reading. See Poguntke, Scarrow and Webb (2016, p. $668)$ and Webb and Keith (2017, p. 33).

19 As Van Biezen, Mair, and Poguntke (2012) argue, Austria is a significant outlier among advanced democracies in terms of party membership. Following their procedures, we excluded Austria from some tests, as in the comparison between old and new democracies presented in Table 1.
} 
Table 1

Party membership, by country

\begin{tabular}{|c|c|c|c|c|c|}
\hline $\begin{array}{l}\mathbf{N} \\
\text { parties }\end{array}$ & Country & $\begin{array}{c}\text { Total membership as \% } \\
\text { of national electorate } \\
(\mathrm{M} / \mathrm{E})^{1}\end{array}$ & $\begin{array}{l}\text { Total national party } \\
\text { membership } 1\end{array}$ & $\begin{array}{c}\text { Mean party } \\
\text { membership as \% of } \\
\text { national electorate } \\
(\mathrm{M} / \mathrm{E})\end{array}$ & $\begin{array}{l}\text { National } \\
\text { electorate }\end{array}$ \\
\hline 5 & Austria & 13.37 & 853,518 & 2.67 & $6,384,331$ \\
\hline 5 & Mexico & 10.87 & $9,085,701$ & 2.17 & $83,563,190$ \\
\hline 10 & Brazil & 8.32 & $11,687,285$ & 0.83 & $140,488,492$ \\
\hline 6 & Israel & 6.22 & 351,668 & 1.04 & $5,656,705$ \\
\hline 11 & Belgium & 4.74 & 379,962 & 0.43 & $8,008,776$ \\
\hline 5 & Italy & 4.49 & $2,106,025$ & 0.90 & $46,905,154$ \\
\hline 7 & Norway & 4.44 & 161,811 & 0.63 & $3,641,753$ \\
\hline 5 & Spain & 4.18 & $1,494,000$ & 0.84 & $35,779,491$ \\
\hline 8 & Denmark & 3.67 & 149,648 & 0.46 & $4,079,910$ \\
\hline 5 & Chile & 3.59 & 486,740 & 0.72 & $13,573,143$ \\
\hline 7 & Sweden & 3.37 & 247,289 & 0.48 & $7,330,432$ \\
\hline 6 & Portugal & 2.97 & 285,828 & 0.50 & $9,624,354$ \\
\hline 10 & Netherlands & 2.47 & 313,958 & 0.25 & $12,689,810$ \\
\hline 4 & Ireland & 2.17 & 69,652 & 0.54 & $3,202,442$ \\
\hline 7 & Germany & 2.15 & $1,329,509$ & 0.31 & $61,903,903$ \\
\hline 5 & $\begin{array}{c}\text { Czech } \\
\text { Republic }\end{array}$ & 1.75 & 147,410 & 0.35 & $8,424,227$ \\
\hline 4 & Australia & 1.67 & 245,702 & 0.42 & $14,722,754$ \\
\hline 2 & France & 1.05 & 453,486 & 0.52 & $43,233,648$ \\
\hline 4 & Hungary & 1.04 & 86,120 & 0.26 & $8,241,488$ \\
\hline 7 & UK & 0.98 & 446,148 & 0.14 & $45,597,461$ \\
\hline 4 & Canada & 0.83 & 201,000 & 0.21 & $24,257,592$ \\
\hline 5 & Poland & 0.78 & 238,544 & 0.16 & $30,762,931$ \\
\hline 132 & $\begin{array}{c}\text { Overall } \\
\text { mean }\end{array}$ & $\mathbf{3 . 8 7} * * *$ & $1,400,955$ & 0.67 & r r \\
\hline 20 & $\begin{array}{l}\text { Mean Latin } \\
\text { America } \\
\text { (refer.) }\end{array}$ & $7.59 * *$ & $7,086,575$ & 1.24 & - \\
\hline 112 & $\begin{array}{l}\text { Mean non- } \\
\text { Latin } \\
\text { America }\end{array}$ & $3.28 * *$ & 503,225 & 0.58 & - \\
\hline 14 & $\begin{array}{l}\text { Mean E. } \\
\text { Europe }\end{array}$ & $1.19 * * *$ & 157,358 & 0.26 & - \\
\hline 45 & $\begin{array}{c}\text { Mean new } \\
\text { democracies }\end{array}$ & $4.20 * *$ & $2,938,954$ & 0.73 & - \\
\hline 87 & \begin{tabular}{|c|} 
Mean old \\
democracies
\end{tabular} & $3.69 * *$ & 522,098 & 0.64 & - \\
\hline \multicolumn{6}{|c|}{ Party families in Latin America } \\
\hline 11 & Center-right & 3.75 & $8,912,197$ & 0.76 & - \\
\hline 9 & Center-left & 5.20 & $12,347,529$ & 1.61 & - \\
\hline
\end{tabular}

Sources: PPDB round 1a data and official records for Latin American countries (Brazil: Superior Electoral Court, TSE; Mexico: National Electoral Institute, INE; Chile: Chilean Electoral Service, Servel). ${ }^{1}$ Only the parties included in the research. Statistically significant differences: $* * * p<0.01 ; * * p<0.05$ (without Austria, in the comparison of means between old and new democracies). 
Regarding the "time component," the analysis shows that the party origin (initial appearance of the party) is statistically associated with the M/E ratio, in the expected way: the older the party, the larger the party membership $(r=0.183 ; p<0.05$; see all the bivariate correlation coefficients in the Appendix). The influence of party origin is stronger in new democracies $(r=0.246)$ than in consolidated ones $(r=0.200)$. Party age (existence in the current regime) does not affect membership with statistical significance, while the duration of democracy affects the M/E only when we exclude the outlier, Austria (Van Biezen, Mair, and Poguntke, 2012): older regimes have less members ( $r=-0.270, p<$ $0.05)^{20}$.

Table 2 presents data on party funding for all 138 parties for which we have data. When we consider the mean party income relative to the polity size (last column), it is clear that Chilean, Brazilian, and Mexican parties have less financing capacity than the PPDB round 1a parties: on average, only 19 cents of euros per registered voter per year in Brazil and Chile, and 44 cents in Mexico. However, if we consider the size of national economies (GDP), there is no difference: on average, each party receives annually 23,000 euros per billion euros of GDP, both in the Latin American cases and in other democracies. Social democratic parties are richer than center-right parties in Latin America.

\footnotetext{
20 As is true of other analyses based on the PPDB data, it should be noted that this conclusion does not consider the longitudinal variation in the size of party membership. For analysis considering the "curvilinear pattern" of party age and M/E rates over time, see Van Haute, Paulis, and Sierens (2017).
} 
Table 2

National party head office income, by country

\begin{tabular}{|c|c|c|c|c|}
\hline $\begin{array}{l}\mathrm{N} \\
\text { parties }\end{array}$ & Country & $\begin{array}{l}\text { Mean income of } \\
\text { national party head } \\
\text { offices (euros) }\end{array}$ & $\begin{array}{c}\text { Mean party income per } \\
\text { billion euros of GDP } \\
\text { (euros) }\end{array}$ & $\begin{array}{c}\text { Mean party income } \\
\text { per registered voter } \\
\text { (euros) }\end{array}$ \\
\hline 2 & France & $60,888,527$ & 28,987 & 1.41 \\
\hline 7 & Germany & $60,701,745$ & 21,764 & 0.98 \\
\hline 5 & Spain & $45,787,541$ & 43,220 & 1.28 \\
\hline 5 & Mexico & $36,875,239$ & 41,183 & 0.44 \\
\hline 5 & Italy & $28,827,778$ & 17,739 & 0.61 \\
\hline 10 & Brazil & $26,430,385$ & 14,420 & 0.19 \\
\hline 4 & Australia & $17,510,742$ & 15,757 & 1.19 \\
\hline 5 & Canada & $15,152,621$ & 11,200 & 0.62 \\
\hline 7 & $\begin{array}{c}\text { United } \\
\text { Kingdom }\end{array}$ & $12,716,844$ & 6,262 & 0.28 \\
\hline 5 & Austria & $12,521,560$ & 40,165 & 1.96 \\
\hline 7 & Sweden & $10,378,283$ & 24,526 & 1.42 \\
\hline 7 & Norway & $10,072,069$ & 26,812 & 2.77 \\
\hline 5 & $\begin{array}{c}\text { Czech } \\
\text { Republic }\end{array}$ & $8,016,845$ & 50,390 & 0.95 \\
\hline 6 & Portugal & $7,102,583$ & 41,164 & 0.37 \\
\hline 12 & Belgium & $6,919,590$ & 17,687 & 0.86 \\
\hline 5 & Poland & $5,324,045$ & 13,566 & 0.17 \\
\hline 10 & Netherlands & $4,508,672$ & 6,997 & 0.36 \\
\hline 8 & Denmark & $3,501,990$ & 13,934 & 0.86 \\
\hline 4 & Ireland & $3,178,000$ & 18,065 & 0.99 \\
\hline 5 & Chile & $2,551,548$ & 13,317 & 0.19 \\
\hline 10 & Israel & $2,494,406$ & 11,986 & 0.44 \\
\hline 4 & Hungary & $2,378,244$ & 23,844 & 0.29 \\
\hline 138 & $\begin{array}{c}\text { Overall } \\
\text { mean }\end{array}$ & $17,447,239$ & 22,863 & $0.85 * * *$ \\
\hline 20 & $\begin{array}{l}\text { Mean Latin } \\
\text { America } \\
\text { (refer.) }\end{array}$ & $21,952,391$ & 22,973 & $0.27 * * *$ \\
\hline 118 & $\begin{array}{l}\text { Mean non- } \\
\text { Latin } \\
\text { America } \\
\end{array}$ & $16,735,899$ & 22,846 & $0.94 * * *$ \\
\hline 14 & $\begin{array}{c}\text { Mean E. } \\
\text { Europe }\end{array}$ & $5,239,711$ & 22,266 & 0.47 \\
\hline 45 & $\begin{array}{c}\text { Mean new } \\
\text { democracies }\end{array}$ & $16,808,304$ & $30,138 * *$ & $0.49 * * *$ \\
\hline 93 & $\begin{array}{c}\text { Mean old } \\
\text { democracies }\end{array}$ & $17,812,345$ & $18,706 * *$ & $1.05 * * *$ \\
\hline \multicolumn{5}{|c|}{ Party families in Latin America } \\
\hline 11 & Center-right & $19,586,117$ & 17,313 & 0.22 \\
\hline 9 & Center-left & $27,332,277$ & 25,140 & 0.29 \\
\hline
\end{tabular}

Sources: PPDB round $1 \mathrm{a}$ data and official records for Latin American countries (TSE, INE, and Servel). Statistically significant differences: $* * * p<0.01 ; * * p<0.05$. 
Table 2 also shows that parties in newer democracies are richer than those in more traditional democracies, when controlling for the national GDP. However, when controlling for the size of national electorates, parties in established democracies perform much better (last column). This indicates that the two factors must be evaluated together, through the GDP per capita. Figure 1 shows that this variable is a strong predictor of party income: the richer the country in relation to the size of its population, the wealthier its parties $(r=$ $0.706, \mathrm{p}<0.01$, adj. $\mathrm{R}^{2}=0.473$ ).

Figure 1

Party income / electorate ratio and GDP per capita 2014, by country

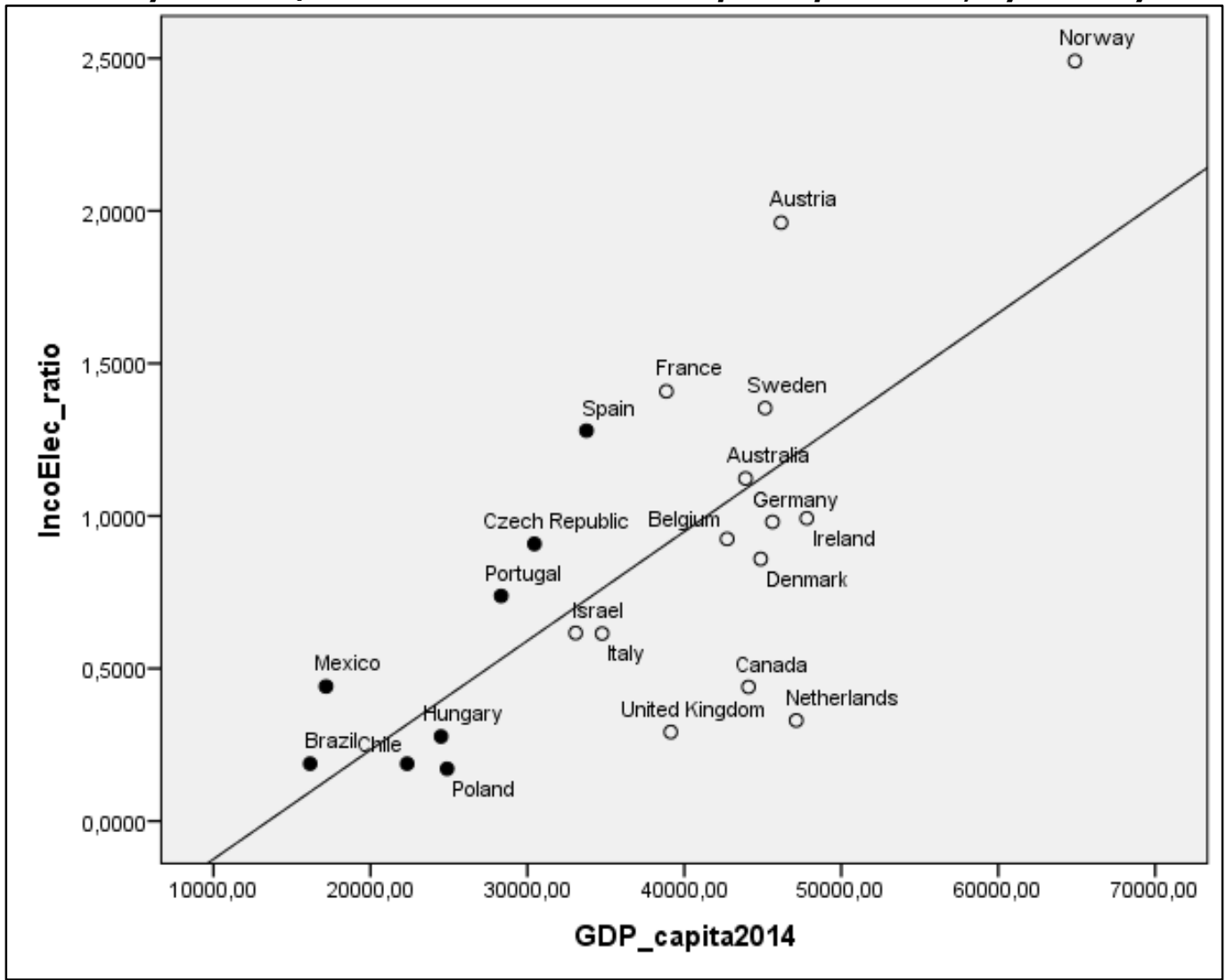

Source: PPDB round 1a data (raw data) and official records for Latin American countries. The newer democracies are highlighted in black.

At the party level, the income is highly influenced by party age and party origin ( $r$ $=0.456$ and $r=0.451$ respectively, $\mathrm{p}<0.01$ ). The association between party origin and income is stronger in established democracies than in newer ones $(r=0.451$ and $r=$ $0.419, \mathrm{p}<0.01)$.

Finally, we evaluate the relative organizational strength using the Party Strength Index (PSI), which aggregates the $z$ scores of M/E and party income/electorate ratios 
TIME AFTER TIME: PARTY ORGANIZATIONAL STRENGTH IN NEW AND OLD DEMOCRACIES

(Webb and Keith, 2017). Among the twenty parties in Latin America, eight have a PSI score higher than the median (-0.51), and only two parties are located in the last quartile of distribution (Figure 2 below). The PRI and PRD are the most powerful parties in Mexico, as well as the PMDB and PT in Brazil.

Figure 2

Party strength index in descending order, by party

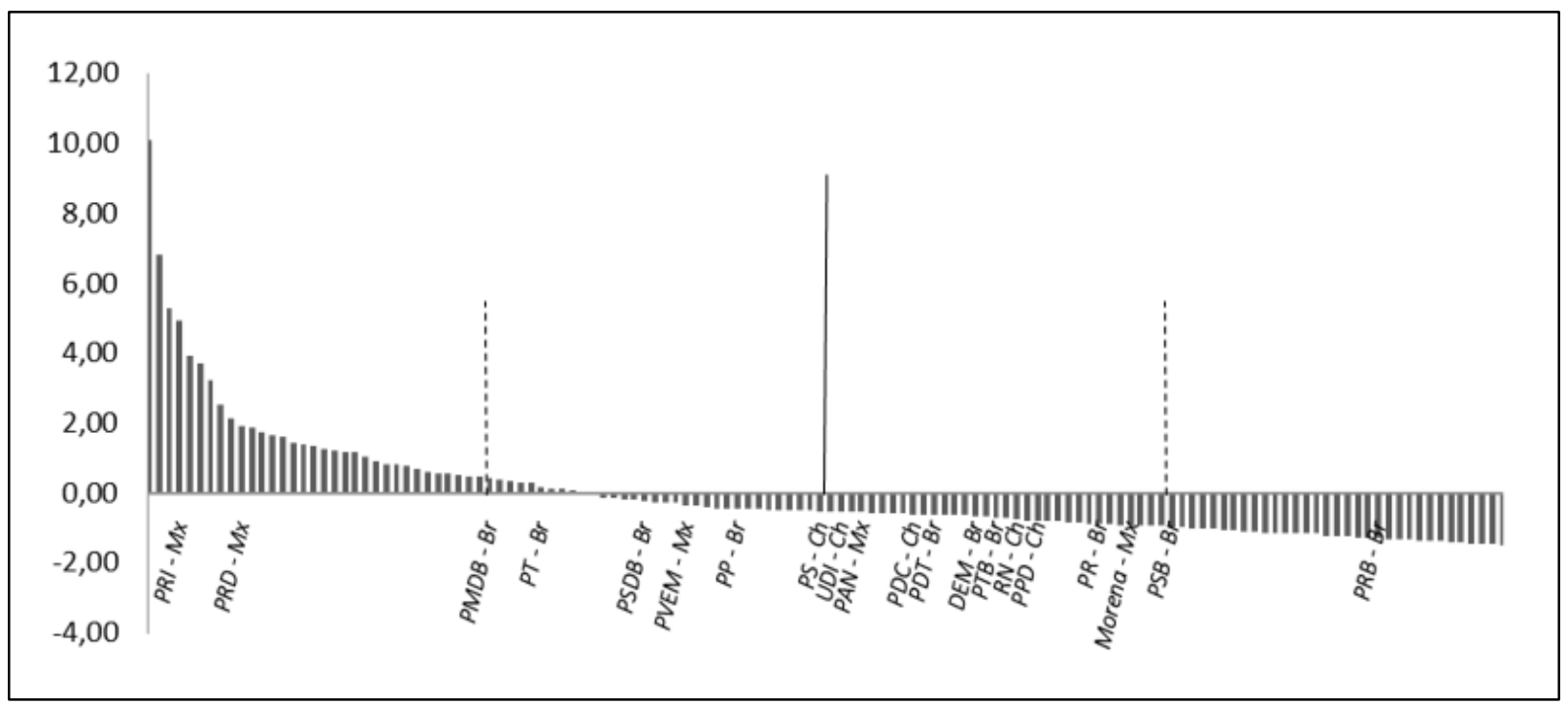

Sources: PPDB round 1a data (raw data, standardized by the authors) and official records for Latin American countries. See all the party scores in the Appendix, Table B.

When we look at the average per country (Table 3 below), it is clear that Mexican parties are stronger than Chilean and Brazilian parties, and older democracies have parties with more resources. The average PSI among new democracies is -0.26 , while in the most advanced democracies it is 0.13 . The figures for the new democracies hide a substantial difference between third-wave democracies (average $=-0.03$ ) and post-communist countries, which have much more fragile parties (average $=-0.75$ ). With regard to party families in Latin America, social democrats and socialists (nine parties) are stronger than conservative parties (11): the averages are 0.33 and -0.54 respectively. 
Table 3

Party Strength Index in descending order, by country

\begin{tabular}{|c|c|c|c|c|}
\hline $\mathbf{N}$ parties & Country & Mean PSI & $\begin{array}{l}\text { Difference between } \\
\text { top two parties }\end{array}$ & $\begin{array}{l}\text { Range between top } \\
\text { and bottom parties }\end{array}$ \\
\hline 5 & Austria & 3.14 & 4.79 & 10.37 \\
\hline 7 & Norway & 1.80 & 3.58 & 7.20 \\
\hline 5 & Mexico & 1.02 & 3.02 & 5.87 \\
\hline 5 & Spain & 0.68 & 1.36 & 5.07 \\
\hline 2 & France & 0.53 & 0.11 & 0.11 \\
\hline 7 & Sweden & 0.43 & 2.36 & 4.55 \\
\hline 6 & Israel & 0.15 & 1.32 & 3.40 \\
\hline 4 & Australia & 0.11 & 0.34 & 2.50 \\
\hline 4 & Ireland & 0.09 & 1.64 & 2.18 \\
\hline 5 & Italy & 0.02 & 0.45 & 2.90 \\
\hline 11 & Belgium & -0.09 & 0.74 & 2.70 \\
\hline 8 & Denmark & -0.13 & 0.13 & 2.20 \\
\hline 7 & Germany & -0.14 & 0.21 & 3.32 \\
\hline 5 & Czech Republic & -0.18 & 0.38 & 1.99 \\
\hline 6 & Portugal & -0.23 & 0.67 & 2.64 \\
\hline 10 & Brazil & -0.51 & 0.28 & 1.72 \\
\hline 5 & Chile & -0.61 & 0.01 & 0.24 \\
\hline 4 & Canada & -0.82 & 0.25 & 1.06 \\
\hline 10 & Netherlands & -0.90 & 0.08 & 0.94 \\
\hline 4 & Hungary & -0.95 & 0.29 & 0.87 \\
\hline 7 & United Kingdom & -1.04 & 0.38 & 1.33 \\
\hline 5 & Poland & -1.16 & 0.03 & 0.49 \\
\hline 132 & $\begin{array}{c}\text { Overall mean } \\
\text { (country aggregated) }\end{array}$ & $0.05 * * *$ & - & - \\
\hline 20 & Mean Latin America (refer.) & -0.15 & - & - \\
\hline 112 & Mean non-Latin America & 0.03 & - & - \\
\hline 14 & Mean Eastern Europe & -0.75 & & \\
\hline 45 & Mean new democracies & -0.26 & - & - \\
\hline 87 & Mean old democracies & 0.13 & - & - \\
\hline
\end{tabular}

Sources: PPDB round 1a data (raw data, standardized by the authors) and official records for Latin American countries. $* * * \mathrm{p}<0.01$.

The variables analyzed so far were included in OLS regression models with party membership, party income, and party strength as dependent variables (separate models for each dependent variable), with both country-level and party-level aggregations. Due to the high levels of multicollinearity between some factors (as the socioeconomic control variables), the tables present only the best model for each dependent variable.

At the country level (Table 4), the HDI has the most significant effect on party membership: the most developed countries have less party members. The GDP per capita is the variable that best predicts the party funding and the overall party strength, with a positive impact on both indicators. On the other hand, the duration of democracy 
(reference is 2014) has no significant effect, when controlled for the socioeconomic context.

\section{Table 4}

OLS regression models at the country level

\begin{tabular}{|l|c|c|c|}
\hline & \multicolumn{3}{|c|}{ Dependent variables } \\
\hline & $\begin{array}{c}\text { Party membership } \\
(\mathbf{M} / \mathbf{E})^{\mathbf{1}}\end{array}$ & $\begin{array}{c}\text { Party income / } \\
\text { electorate ratio }\end{array}$ & $\begin{array}{c}\text { Party Strength } \\
\text { Index }\end{array}$ \\
\hline HDI & $-0.495(0.016) * *$ & - & - \\
\hline GDP per capita & - & $0.706(0.000) * * *$ & $0.370(0.000) * * *$ \\
\hline GDP & - & - & - \\
\hline Duration of democracy (years) & - & - & - \\
\hline Intercept & $0.041(0.014) * * *$ & $-0.482(0.312) * * *$ & $-1.096(0.667) * * *$ \\
\hline Adjusted R ${ }^{2}$ & 0.205 & 0.473 & 0.093 \\
\hline N & 21 & 22 & 22 \\
\hline
\end{tabular}

Source: Calculated by the authors from PPDB round 1a data (raw data, standardized by the authors) and official records for Latin American countries.

** $\mathrm{p}<0.05$; *** $\mathrm{p}<0.01$. Standard errors in parentheses. ${ }^{1}$ Without Austria, see Van Biezen, Mair, and Poguntke (2012).

When we turn to the multilevel analysis, with party-aggregated data controlled for contextual factors (Table 5), the party origin stands out as the main explanatory factor of both PSI and party income, ahead of socioeconomic contextual variables and other "time components" (duration of democracy and party age). Controlling for other variables, an additional decade of party origin means an increase of 0.15 in the party's PSI score. This impact is notable considering that $97 \%$ of the parties in the study are positioned between 3.92 and -1.47 on the PSI scale (average $=0.00$ ). The 'historical origins' of parties also have a significant effect on the M/E ratio. In this case, both contextual and party variables have a significant impact, with the prevalence of the former: old parties in contexts of low HDI have more members. 
Table 5

OLS regression models at the party level

\begin{tabular}{|l|c|c|c|}
\hline & \multicolumn{3}{|c|}{ Dependent variables } \\
\hline & $\begin{array}{c}\text { Party membership } \\
(\mathbf{M} / \mathbf{E})^{\mathbf{1}}\end{array}$ & $\begin{array}{c}\text { Party income / } \\
\text { electorate ratio }\end{array}$ & $\begin{array}{c}\text { Party Strength } \\
\text { Index }\end{array}$ \\
\hline HDI & $-0.295(0.017) * *$ & $0.321(1.969) * *$ & $0.102(3.752)$ \\
\hline GDP per capita & - & - & - \\
\hline GDP & - & - & - \\
\hline Duration of democracy (years) & $-0.069(0.000)$ & $-0.122(0.003)$ & $-0.145(0.005)$ \\
\hline Party age (years) & - & - & - \\
\hline Party origin (years) & $0.212(0.000) * *$ & $0.399(0.002) * * *$ & $0.395(0.003) * * *$ \\
\hline Intercept & $0.036(0.013) * *$ & $-4.096(1.559) * *$ & $-3.085(2.870) * * *$ \\
\hline Adjusted R ${ }^{2}$ & 0.104 & 0.241 & 132 \\
\hline N & 127 & 132 \\
\hline
\end{tabular}

Source: Calculated by the authors from PPDB round 1a data (raw data, standardized by the authors) and official records for Latin American countries.

** $\mathrm{p}<0.05 * * * \mathrm{p}<0.01$. Standard errors in parentheses. ${ }^{1}$ Without Austrian parties, see Van Biezen, Mair, and Poguntke (2012).

The models on Table 6 include dummy variables to test the differences between Latin America and Eastern Europe (three countries in each). When controlling for region and socioeconomic context, the duration of democracy is the main explanatory variable of party membership: the older the democracy, the lower the quantity of party members. However, this effect is not constant across the regions. Latin American parties have more members than parties in the other regions (though not significant at the level 0.5), while Eastern European parties have lower levels of membership. As the most important finding, party origin remains as the main explanatory variable of both income and party strength, with strong and significant positive effects. The impact of party origin on the organizational strength remains almost the same when we include the regions in the model (a decade brings an increase of 0.14 in the PSI). This means that the time component has a consistent effect on the organizational strength at the party level. 
Table 6

OLS regression models at the party level, with regions

\begin{tabular}{|l|c|c|c|}
\hline & \multicolumn{3}{|c|}{ Dependent variables } \\
\hline & $\begin{array}{c}\text { Party membership } \\
(\mathbf{M} / \mathbf{E})^{\mathbf{1}}\end{array}$ & $\begin{array}{c}\text { Party income / } \\
\text { electorate ratio }\end{array}$ & $\begin{array}{c}\text { Party Strength } \\
\text { Index }\end{array}$ \\
\hline HDI & - & $0.294(3.093)$ & $0.140(5.396)$ \\
\hline GDP per capita & - & - & - \\
\hline GDP & $-0.142(0.000)$ & - & - \\
\hline Duration of democracy (years) & $-0.287(0.000)^{* *}$ & $-0.165(0.003)$ & $-0.259(0.006)$ \\
\hline Party age (years) & - & - & - \\
\hline Party origin (years) & $0.187(0.000)^{* *}$ & $0.391(0.002)^{* * *}$ & $0.376(0.003)^{* * *}$ \\
\hline Latin America & $0.213(0.002)$ & $-0.059(0.407)$ & $-0.026(0.711)$ \\
\hline Eastern Europe & $-0.251(0.001)^{* *}$ & $-0.078(0.163)$ & $-0.172(0.285)$ \\
\hline Intercept & $0.009(0.002)^{* * *}$ & $0.805(0.277)$ & $-3.543(4.571)$ \\
\hline Adjusted R ${ }^{2}$ & 0.170 & 0.233 & 0.144 \\
\hline N & 127 & 132 & 132 \\
\hline
\end{tabular}

Source: Calculated by the authors from PPDB round 1a data (raw data, standardized by the authors) and official records for Latin American countries.

** $\mathrm{p}<0.05$; *** $\mathrm{p}<0.01$. Standard errors in parentheses. ${ }^{1}$ Without Austrian parties, see Van Biezen, Mair, and Poguntke (2012).

\section{Discussion}

The results presented in the previous section corroborate some of the expectations derived from the literature. Regarding our first hypothesis, the tests of mean differences show that parties in established democracies are stronger than those of newer democracies, primarily because they are much richer. However, when controlling for the socioeconomic context (GDP or HDI) and the party-level variables (party origin), this relationship become less pronounced. This finding suggests that duration of democracy should not be the only factor to be considered when analyzing party strength and party institutionalization in a comparative perspective. The socioeconomic context matters (Tavits, 2013).

Overall, older democracies have less party members. However, as they are the wealthiest countries, the party income partially compensates for the difficulties in mass mobilization-which confirms previous findings (Bartolini and Mair, 2001; Mair and Van Biezen, 2001; Scarrow, Webb, and Poguntke, 2017). Supporting the second hypothesis, the findings show that not all recently democratized countries perform in the same way. Controlling for national GDP, party-level variables and size of the electorates, the parties in the three Latin American cases are stronger than the Eastern European parties, as the mass mobilization compensates for the lack of money only in the first group.

While differences between countries and regions are relevant, party-level variables also need to be considered. A second key contribution concerns the role played by the 
historical party origin: the organizational legacy is an important factor in explaining party strength. So far, only the party foundation under the current democratic regime has been included in analyses about party institutionalization or party strength (Casal Bértoa, 2017). In all the tests, the "ancestral" party origin in previous democratic or authoritarian regimes proved to be more relevant than the party foundation in explaining the variations in organizational strength, in both new and established democracies (the party-origin date is prior to the party age in 36 of the 132 cases). Parties such as the PSOE in Spain (originated in 1879), the PMDB in Brazil (1965), the PRI in Mexico (1929), the Swedish Social Democrats (1889), and Chile's Socialist Party (1933) were in an advantageous position in the beginning of the democratization process, due to their previous organizational trajectories. This finding endorses the importance of infrastructure and brand inheritance in party strength and survival, a point highlighted in previous studies (Van Biezen, 2003; see the authors in Levitsky et al., 2016).

Time is crucial for the consolidation of party organizations, mainly at the party level, which produces large within-country variations in both advanced and newer democracies (Dix, 1992; Tavits, 2013; Gauja, 2017). In the multilevel analysis, the effects of the socioeconomic context and the duration of democracy are mediated by the differences at the party level. Overall, time proved to be more important at the party level than at the national level. In all but one test, the effects of party origin proved stronger than the impact of duration of democracy (the exception is the M/E ratio in Table 6). Therefore, the differences between new and old democracies can be explained, at least in part, by the differences in terms of party origin. Established democracies have many more older parties than newer democracies do: in the former, the averages are 70 years old for party origin and 60 years old for party age; in the latter, the averages are 44 and 26 years respectively. The findings suggest that, in comparative perspective, old parties in new democracies can be stronger than new parties in old democracies.

Finally, the data support the view about the bigger capacity (and willingness) of socialist and social-democratic parties to build strong organizations in Latin America (Ames and Power, 2007; Levitsky et al., 2016), which replicates certain findings about established democracies (Webb and Keith, 2017). Particularly about Latin America, the 11 parties in the database that could be classified as conservative/right-wing parties (according to the PPDB criteria) are poorer and mobilize less members than the nine social-democratic and socialist parties ${ }^{21}$. A systematic analysis about the influence of ideology and the patterns related to the party families can be a productive path for further research.

\footnotetext{
21 While party membership does not significantly oscillate in an interval as short as the period considered in the PPDB project (2011-14), party funding is more unstable, as it depends on factors such as the electoral cycle (the raising of private and public resources for general elections), and the electoral performance (which influences the distribution of public money). One could note, therefore, that this difference may reflect a snapshot of a period in which left-wing parties were governing Brazil (since 2003) and Mexico (since December 2012). Besides, over almost three decades, the Chilean left-wing Concertacíon/Nueva Mayoría was out of power for only four years (2010-2014). Definite results about this question would involve the gathering of data from more Latin American countries and over a longer period.
} 


\section{Conclusion}

In short, the historical party origin can be considered a crucial dimension for the analysis of party organizational development and institutionalization. Why does time matter? It takes time to develop societal attachments and organizational complexity and autonomy, as well as to adapt to the environment (Panebianco, 1988). The particular conditions under which the parties develop should also matter. During the golden age of parties in the most traditional democracies (1950s and 1960s), parties that experienced the institutionalization process as opposition parties for a long time tended to build stronger organizations, when compared to parties in government (Panebianco, 1988, chapters 45). However, access to government and to public resources is more important for organizational strengthening and survival in contemporary democracies, which may have reversed this equation (Katz and Mair, 2009). The conditions of institutionalization and the microfoundations of the time effect on organizational change and strengthening (Pierson, 2004) should be explored in future research, probably in case studies with more qualitative methods.

The same generational dilemmas seem to affect the parties founded in the late 20th century: organizations built by (and for) the party in public office face, with strong state regulation, in a social and technological environment that did not require the construction of extensive communication channels with the electorate. This generational patternmainly at the party level-seems to be more relevant than regional distinctions (Van Biezen, 2003).

In this sense, the article shows the viability and importance of adopting crossregional perspectives in the study of party organizations in Latin America. The major difference between the Latin American cases and the PPDB round 1a parties is about party finance-which is expected given the low per capita income in the region. However, Chilean, Brazilian, and Mexican parties are better able to recruit members than Eastern European parties, due to the totalitarian legacy of post-communist contexts (Van Biezen, 2003, p. 37-38). Party members are still important: they may represent an alternative multidimensional resource to political parties in the poorest and most unequal democracies, where other resources (money) are limited (Norris, 2002; Scarrow, 2015).

Although highly discontinuous, parties in Latin America have historical trajectories that make the difference today. The results for Eastern Europe, on the other side, suggest that the legacy of the past does not always bring positive effects. The differences between the two regions are also connected to the particularities of the democratic transitions. While left-wing parties gradually entered the party systems in several Latin American countries (Levitsky et al., 2016), in Eastern Europe the totalitarian legacy had a negative impact on the consolidation of left-wing popular parties (Van Biezen, 2003). When we consider that socialist and social democratic parties put more effort into building strong organizations everywhere (Webb and Keith, 2017), these particularities also influence the results in the 
cross-regional analysis. Parties such as the PS in Chile, the PRD in Mexico, and the PT in Brazil made heavy investments in mass mobilization and organizational strengthening since (re)democratization.

Overall, the findings suggest that parties in Brazil, Chile, and Mexico are comparable to the 'usual suspects' normally included in cross-national research on party organizations. As in the majority of the established democracies, parties in most Latin American countries operate under rigid state regulations and have formal members, formal processes, and executive and deliberative organs with perennial functioning (not only during elections), disposed in hierarchical structures (Molenaar, 2017). The results also challenge the assumptions about the "exceptional weakness" of party organizations in the region. Of course, the three countries analyzed here do not tell the full story of Latin American parties. Following the PPDB criteria, we selected the electorally strongest parties, from three party systems with relatively high levels of institutionalization. In this sense, a next step would be the inclusion of other countries in cross-regional comparative studies, particularly those with lower levels of party system institutionalization, such as Argentina and Peru (Mainwaring, 2018).

This article shows that time matters. However, other factors should also be considered when analyzing the differences in terms of party strength. The presidential system-predominant in Latin America-does not seem to be a decisive factor in explaining the differences in terms of party strength in a cross-national perspective. This does not mean that the separation of powers is irrelevant to party organizations. As we argued about the time effect, this impact has never been systematically tested to date. As noted by Key (1964) long ago, parties in presidential systems face governing dilemmas when their presidential candidates succeed. The party in public office is split into two groups, the party's executive and legislative branches, which may conflict with each other regarding presidential appointments, policies, and strategies. As the parliamentary group does not have the power to dismiss the president, these conflicts can be quite severe 22 .

Besides the presidential system, other institutional factors (e.g. electoral system, party law, and federal arrangement) should be addressed in future research as possible drivers of variations in party strength across nations. At the party level, the conditions under which the party was founded (authoritarian versus democratic contexts), the participation in the national government, the electoral performance, and strategic choices made by party elites can also be hypothesized in future studies. On the other hand, the party strength may also be regarded as an independent variable, affecting voters' behavior (electoral performance, party ID, trust in political institutions, and support for democracy) and political outcomes, such as the policy-making and the legislative behavior (Scarrow, Webb, and Poguntke, 2017). In this line, there are exploratory findings showing that parties' organizational strength affects party unity in parliament (discipline), not only in

22 See Samuels and Shugart (2010) for a recent discussion about the topic. 
Europe or in established democracies (Tavits, 2013; Little and Farrell, 2017) but also in Brazil (Ribeiro, Locatelli, and Assis, 2018).

As the 2018 general elections in Mexico and Brazil have demonstrated, organizational strength does not guarantee the stability of party systems or the maintenance of electoral bases of major parties. The advancement of anti-establishment, far-right movements and leaders in countries as different as Brazil, Germany, Italy, and Austria has challenged the traditional parties, breaking the expected association between organizational strength and other processes and outcomes. Nevertheless, strong party organizations remain important for new democracies (Tavits, 2012). In political systems with high levels of instability, which have to deal with significant environmental challenges, such as the extreme social inequality in Latin America, strong parties are expected to increase the predictability about the future and to function as drivers of political professionalization, by providing filters in the processes of political recruitment (Alcántara Sáez, 2012). As highlighted by Dix (1992) in his initial diagnosis, political parties may still be important for the consolidation of democracy in contemporary Latin America.

\section{Bibliographic references}

AlCÁNTARA SÁEZ, M. ¿Instituciones o máquinas ideológicas?. Barcelona: Institut de Ciènces Polítiques i Socials, 2004.

. "Partidos políticos en América Latina: hacia una profesionalización de calidad".

Convergencia: Revista de Ciencias Sociales, vol. 58, 2012.

Alcántara Sáez, M.; Freidenberg, F. (eds.). Partidos políticos de América Latina. Ciudad de Mexico, DF: Fondo de Cultura Económica, 2001.

AMES, B. The deadlock of democracy in Brazil. Ann Arbor: University of Michigan Press, 2001.

AMES, B.; PoWer, T. Parties and governability in Brazil. In: WeBB, P.; WHITE, S. (eds.). Party politics in new democracies. Oxford: Oxford University Press, p. 179-212, 2007.

AngelL, A. The durability of the party system in Chile. In: WebB, P.; WhITE, S. (eds.). Party politics in new democracies. Oxford: Oxford University Press, p. 275-304, 2007.

BARTOLINI, S.; MAIR, P. Challenges to contemporary political parties. In: DiAMOND, L.; GUNTHER, R. (eds.). Political parties and democracy. Baltimore: John Hopkins University Press, p. 327-343, 2001.

Braga, M. S.; Ribeiro, P. F.; Amaral, O. El sistema de Partidos en Brasil: estabilidad e institucionalización (1982-2014). In: FreIDENBERG, F. (ed.). Los sistemas de partidos de América Latina (1978-2015) - Tomo 2. Ciudad de México, DF: Instituto Nacional Electoral, p. 69-134, 2016.

CARLIN, R.; Singer, M.; ZeCHMEISTER, E. (eds.). The Latin American voter: pursuing representation and accountability in challenging contexts. Ann Arbor: University of Michigan Press, 2015.

CARRERAS, M. "Party systems in Latin America after the third wave: a critical re-assessment". Journal of Politics in Latin America, vol. 4, p. 135-153, 2012.

Carreras, M.; CASTAÑeda-Angarita, N. "Who votes in Latin America? A test of three theoretical perspectives". Comparative Political Studies, vol. 47, p. 1.079-1.104, 2014. 
CASAL BÉRTOA, F. "Political parties or party systems? Assessing the 'myth' of institutionalisation and democracy". West European Politics, vol. 40, p. 402-429, 2017.

CASAL BÉRTOA, F., et al. "The world upside down: delegitimising political finance regulation". International Political Science Review, vol. 35, p. 355-375, 2014.

Cheibub, J. A.; Elkins, Z.; GinsbURG, T. "Latin American presidentialism in comparative and historical perspective". Public Law and Legal Theory Working Paper, vol. 361, 2011.

Cheibub, J. A.; Gandhi, J.; VReeland, J. R. "Democracy and dictatorship revisited". Public Choice, vol. 143, p. $67-101,2010$.

COLEMAN, J. "Party organizational strength and public support for parties". American Journal of Political Science, vol. 40, p. 805-824, 1996.

CotTer, C., et al. Party organizations in American politics. Pittsburgh: University of Pittsburgh Press, 1989.

DIX, R. "Democratization and the institutionalization of Latin American political parties". Comparative Political Studies, vol. 24, p. 488-511, 1992.

DoŠEK, T. "Party membership in Latin American political parties: what is the role of the 'militantes'?" Paper prepared for the 42nd ECPR Joint Sessions of Workshops, Salamanca, Spain, 2014.

GALLAGHER, M. Election indices dataset. Available at:

https://www.tcd.ie/Political_Science/people/michael_gallagher/EISystems/Docts/ElectionIndices.pdf. Accessed: 15 Sept. 2018.

GaUjA, A. Party reform: the causes, challenges, and consequences of organizational change. Oxford: Oxford University Press, 2017.

GiBson, J., et al. "Assessing party organizational strength". American Journal of Political Science, vol. 27, p. 193-222, 1983.

HARMEL, R.; JANDA, K. "An integrated theory of party goals and party change". Journal of Theoretical Politics, vol. 6, p. 259-287, 1994.

HARMEL, R.; SVASAND, L.; MJeLDE, H. "Party institutionalization and de-institutionalization: concepts and indicators". Paper prepared for the 44th ECPR Joint Sessions of Workshops, Pisa, Italy, 2016.

HARMEL, R.; TAYLOR-ROBINSON, M. "Application of the integrated theory of party change to Latin America's volatile party systems". Paper prepared for the 5th Congress of CEISAL, Brussels, Belgium, 2007.

JANDA, K. Political parties. New York: The Free Press, 1980.

. "Cross-national measures of party organizations and organizational theory". European Journal of Political Research, vol. 11, p. 319-332, 1983.

JANDA, K.; COLMAN, T. "Effects of party organization on performance during the 'golden age' of parties". Political Studies, vol. 46, p. 611-632, 1998.

KATZ, R.; MAIR, P. (eds.). Party organizations. London: Sage, 1992.

$\overline{766,2009}$.

. "The cartel party thesis: a restatement". Perspectives on Politics, vol. 7, n 4, p. 753-

KEY, V. O. Politics, parties and pressure groups. New York: Crowell, 1964.

LEVITSKY, S. "Inside the black box: recent studies of Latin American party organizations". Studies in Comparative International Development, vol. 36, p. 92-110, 2001. 
TIME AFTER TIME: PARTY ORGANIZATIONAL STRENGTH IN NEW AND OLD DEMOCRACIES

LEVITSKY, S., et al. Challenges of party-building in Latin America. Cambridge: Cambridge University Press, 2016.

LiJPhART, A. Patterns of democracy. New Haven: Yale University Press, 1999.

Limongi, F.; CorteZ, R. "As eleições de 2010 e o quadro partidário". Novos Estudos Cebrap, vol. 88, p. 21-37, 2010.

LitTle, C.; Farrell, D. Party organization and party unity. In: Scarrow, S.; WebB, P.; PogunTKE, T. (eds.). Organizing political parties. Oxford: Oxford University Press, p. 285-306, 2017.

Londoño, J. F.; Zovatto, D. Latin America. In: Falguera, E.; Jones, S.; Ohman, M. (eds.). Funding of political parties and election campaigns. Stockholm: International Idea, p. 128-171, 2014.

LUPU, N. Partisanship in Latin America. In: CARLin, R.; Singer, M.; ZeChMEISTer, E. (eds.). The Latin American voter: pursuing representation and accountability in challenging contexts. Ann Arbor: University of Michigan Press, p. 226-245, 2015.

Party brands in crisis. Cambridge: Cambridge University Press, 2016.

MAINWARING, S. Party system institutionalization in contemporary Latin America. In: MAINWARING, S. (ed.). Party systems in Latin America: institutionalization, decay, and collapse. New York: Cambridge University Press, p. 34-70, 2018.

MaInWARING, S.; SCUlly, T. Party systems in Latin America. In: MAINWARING, S.; Scully, T. (eds.). Building democratic institutions. Stanford: Stanford University Press, p. 1-34, 1995.

Mainwaring, S.; Shugart, M. Presidentialism and democracy in Latin America. Cambridge: Cambridge University Press, 1997.

MAINWARING, S; TORCAL, M. Party system institutionalization and party system theory after the third wave of democratization. In: KATZ, R.; CROTTY, W. (eds.). Handbook of party politics. London: Sage Publications, p. 204-226, 2006.

MaIR, P.; VAN Biezen, I. "Party membership in twenty European democracies, 1980-2000". Party Politics, vol. 7, p. 5-21, 2001.

Melo, C. R.; CÂMARA, R. "Estrutura da competição pela presidência e consolidação do sistema partidário no Brasil". Dados, vol. 55, n 1, p. 71-117, 2012.

Meneguello, R.; Arquer, M. Las elecciones brasileñas de 2014: un país partido por la mitad. In: Alcántara, M.; BuQuet, D.; TAginA, M. L. (eds.). Elecciones y partidos en América Latina en el cambio de ciclo. Madrid: Centro de Investigaciones Sociológicas, p. 75-104, 2018.

MOLENAAR, F. "Changing the rules of the game: the development and reform of party law in Latin America". PhD Dissertation. Leiden University, 2017.

NAdeAu, R., et al. Latin American elections: choice and change. Ann Arbor: University of Michigan Press, 2017.

Norris, P. Democratic Phoenix. Cambridge: Cambridge University Press, 2002.

PAleRMO, V. "Brazilian political institutions: an inconclusive debate". Brazilian Political Science Review, vol. 10, p. 1-29, 2016.

PALMA, E. Political parties and democratization in Mexico: the endless chain of electoral reforms. In: LAWSON, K.; LANZARo, J. (eds.). Political parties and democracy, vol. 1. Santa Barbara: Praeger, p. $150-171,2010$.

Panebianco, A. Political parties: organization and power. Cambridge: Cambridge University Press, 1988. 
PIERSON, P. Politics in time: history, institutions and social analysis. Princeton: Princeton University Press, 2004.

POGUNTKE, T.; SCARROW, S.; WEBB, P. "Party rules, party resources and the politics of parliamentary democracies: how parties organize in the 21st century". Party Politics, vol. 22, p. 1-18, 2016.

PONCE, A. "Meet the militante: the configuration of grassroots party membership in Latin America". Paper prepared for the 7th Congress of CEISAL, Porto, Portugal, 2013.

PONCE, A.; SCARROW, S. "Which members? Using cross-national surveys to study party membership". Party Politics, vol. 22, p. 679-690, 2016.

RaILE, E.; Pereira, C.; Power, T. "The executive toolbox: building legislative support in a multiparty presidential regime". Political Research Quarterly, vol. 64, p. 323-334, 2011.

Ribeiro, P. F. "El modelo de partido cartel y el sistema de partidos de Brasil". Revista de Ciencia Política, Santiago, vol. 33, p. 607-629, 2013.

. "What do these people want? Membership and activism in Brazilian political parties". Paper prepared for the 42nd ECPR Joint Sessions of Workshops, Salamanca, Spain, 2014.

Ribeiro, P. F.; LocatelLI, L. B.; Assis, P. P. F. "Acompanho meu partido: força e disciplina partidária na Câmara dos Deputados (2011-2014)". Paper prepared for the 11th Meeting of ABCP, 2018.

Samuels, D.; Shugart, M. Presidents, parties and prime ministers. Cambridge: Cambridge University Press, 2010.

SARTORI, G. "Concept misformation in comparative politics". American Political Science Review, vol. 64, p. $1.033-1.053,1970$.

SCARRow, S. Beyond party members. Oxford: Oxford University Press, 2015.

SCARROW, S.; WEBB, P. Investigating party organizations: strutures, resources, and representative strategies. In: SCARROW, S.; WEBB, P.; POGUNTKE, T. (eds.). Organizing political parties. Oxford: Oxford University Press, p. 1-27, 2017.

SCARrow, S.; WebB, P.; PoguntKE, T. (eds.). Organizing political parties: representation, participation and power. Oxford: Oxford University Press, 2017.

SPECK, B.; BRAGA, M.; COSTA, V. "Estudo exploratório sobre filiação e identificação partidária no Brasil". Revista de Sociologia e Política, vol. 23, n 56, p. 125-148, 2015.

TAVITS, M. "Organizing for success: party organizational strength and electoral performance in postcommunist Europe". Journal of Politics, vol. 74, p. 83-97, 2012.

Press, 2013.

Post-communist democracies and party organization. Cambridge: Cambridge University

Valenzuela, J. S. "The origins and transformations of the Chilean party system". Working Paper 215, Kellogg Institute, University of Notre Dame, 1995.

VAn Biezen, I. Political parties in new democracies. New York: Palgrave, 2003.

VAN Biezen, I.; MAIR, P.; PogUnTKE, T. "Going, going,... gone? The decline of party membership in contemporary Europe". European Journal of Political Research, vol. 51, p. 24-56, 2012.

Van Haute, E.; Paulis, E.; Sierens, V. "Assessing party membership figures: the mapp dataset". European Political Science, p. 1-12, 2017.

Von BeYME, K. Political parties in Western democracies. Aldershot: Gower, 1985.

WARE, A. Citizens, parties, and the State. Cambridge: Polity Press, 1987. 
TIME AFTER TIME: PARTY ORGANIZATIONAL STRENGTH IN NEW AND OLD DEMOCRACIES

"Exceptionalism, political science and the comparative analysis of political parties". Government and Opposition, vol. 46, p. 411-435, 2011.

WeBB, P.; KeITH, D. Assessing the strength of party organizational resources. In: SCARROW, S.; WeBB, P.; PoguntKe, T. (eds.). Organizing political parties. Oxford: Oxford University Press, p. 31-61, 2017.

WebB, P.; PoguntKe, T.; Scarrow, S. Conclusion: the study of party organization. In: Scarrow, S.; WeBB, P.; PoguntKe, T. (eds.). Organizing political parties. Oxford: Oxford University Press, p. 307$320,2017$.

WebB, P.; White, S. (eds.). Party politics in new democracies. Oxford: Oxford University Press, 2007.

WiLls-Otero, L. "From party systems to party organizations: the adaptation of Latin American parties to changing environments". Journal of Politics in Latin America, vol. 1, p. 123-141, 2009.

. "The electoral performance of Latin American traditional parties, 1978-2006: does the internal structure matter?". Party Politics, vol. 22, p. 758-772, 2014.

\section{Appendix}

Table A

Selected parties in Brazil, Mexico and Chile

\begin{tabular}{|c|c|c|c|}
\hline Country & Party acronym & Full name & Party family (PPDB families)* \\
\hline \multirow{10}{*}{ Brazil } & DEM & Democrats & Christian democrats/Conservatives \\
\hline & PDT & Democratic Labour Party & Social democrats \\
\hline & PMDB & Brazilian Democratic Movement & Christian democrats/Conservatives \\
\hline & $\mathrm{PP}$ & Progressive Party & Christian democrats/Conservatives \\
\hline & PR & Party of the Republic & Christian democrats/Conservatives \\
\hline & PRB & Brazilian Republican Party & Christian democrats/Conservatives \\
\hline & PSB & Socialist Party & Social democrats \\
\hline & PSDB & Brazilian Social Democracy & Liberals \\
\hline & PT & Workers' Party & Social democrats \\
\hline & PTB & Brazilian Labour Party & Christian democrats/Conservatives \\
\hline \multirow{5}{*}{ Mexico } & PAN & National Action Party & Christian democrats/Conservatives \\
\hline & PRI & Institutional Revolutionary Party & Social democrats \\
\hline & PRD & Party of the Democratic Revolution & Social democrats \\
\hline & PVEM & Ecologist Green Party & Greens \\
\hline & Morena & National Regeneration Movement & Social democrats \\
\hline \multirow{5}{*}{ Chile } & PDC & Christian Democratic Party & Christian democrats/Conservatives \\
\hline & PPD & Party for Democracy & Social Democrats \\
\hline & PS & Socialist Party & Social Democrats \\
\hline & RN & National Renewal & Liberals \\
\hline & UDI & Independent Democratic Union & Christian democrats/Conservatives \\
\hline
\end{tabular}

Source: Elaborated by the authors.

* The classification follows the categories adopted by the PPDB project and relies upon the labels provided by the MAPP project (Van Haute, Paulis, and Sierens, 2017). 
Table B

Party strength index rankings in descending order, by party

\begin{tabular}{|c|c|c|c|}
\hline Rank & Party & Country & PSI score \\
\hline 1 & People's Party & Austria & 10.09 \\
\hline 2 & Labour Party & Norway & 6.83 \\
\hline 3 & Social Democratic Party & Austria & 5.30 \\
\hline 4 & Institutional Revolutionary Party-PRI & Mexico & 4.96 \\
\hline 5 & People's Party & Spain & 3.92 \\
\hline 6 & Social Democrats & Sweden & 3.74 \\
\hline 7 & Conservative Party & Norway & 3.25 \\
\hline 8 & Socialist Party & Spain & 2.56 \\
\hline 9 & Likud & Israel & 2.15 \\
\hline 10 & Party of the Democratic Revolution-PRD & Mexico & 1.94 \\
\hline 11 & Social Democratic Party & Germany & 1.89 \\
\hline 12 & Progress Party & Norway & 1.75 \\
\hline 13 & Christian Democratic Union & Germany & 1.68 \\
\hline 14 & The People of Freedom & Italy & 1.64 \\
\hline 15 & Fine Gael & Ireland & 1.46 \\
\hline 16 & Moderate Party & Sweden & 1.38 \\
\hline 17 & Socialist Party & Belgium & 1.35 \\
\hline 18 & Liberal Party & Australia & 1.28 \\
\hline 19 & Social Democratic Party & Portugal & 1.23 \\
\hline 20 & Social Democrats & Denmark & 1.20 \\
\hline 21 & Democratic Party & Italy & 1.19 \\
\hline 22 & Liberals & Denmark & 1.07 \\
\hline 23 & Labor Party & Australia & 0.94 \\
\hline 24 & Civic Democratic Party & Czech Republic & 0.85 \\
\hline 25 & Kadima & Israel & 0.83 \\
\hline 26 & Christian Democratic Party & Norway & 0.77 \\
\hline 27 & Freedom Party & Austria & 0.72 \\
\hline 28 & Christian-Democrat and Flemish & Belgium & 0.61 \\
\hline 29 & Union for a Popular Movement & France & 0.58 \\
\hline 30 & Socialist Party & Portugal & 0.56 \\
\hline 31 & Labor Party & Israel & 0.54 \\
\hline 32 & Social Democratic Party & Czech Republic & 0.47 \\
\hline 33 & Socialist Party & France & 0.47 \\
\hline 34 & Brazilian Democratic Movement-PMDB & Brazil & 0.45 \\
\hline 35 & Centre Party & Sweden & 0.41 \\
\hline 36 & Communist Party & Portugal & 0.33 \\
\hline 37 & Socialist Party Alternative & Belgium & 0.32 \\
\hline 38 & Centre Party & Norway & 0.29 \\
\hline 39 & Workers' Party-PT & Brazil & 0.17 \\
\hline 40 & Open Flemish Liberals and Democrats & Belgium & 0.14 \\
\hline 41 & Conservatives & Denmark & 0.14 \\
\hline 42 & New Flemish Alliance & Belgium & 0.11 \\
\hline 43 & Socialist Left Party & Norway & 0.06 \\
\hline 44 & Reform Movement & Belgium & 0.01 \\
\hline 45 & Labour Party & United Kingdom & -0.12 \\
\hline
\end{tabular}




\begin{tabular}{|c|c|c|c|}
\hline 46 & Alliance for the Future & Austria & -0.15 \\
\hline 47 & Labour Party & Ireland & -0.18 \\
\hline 48 & Fianna Fáil & Ireland & -0.19 \\
\hline 49 & Brazilian Social Democracy-PSDB & Brazil & -0.23 \\
\hline 50 & Liberal Party & Canada & -0.25 \\
\hline 51 & The Greens & Austria & -0.28 \\
\hline 52 & Communist Party & Czech Republic & -0.28 \\
\hline 53 & Ecologist Green Party-PVEM & Mexico & -0.36 \\
\hline 54 & Liberal Party & Norway & -0.37 \\
\hline 55 & Socialist People's Party & Denmark & -0.41 \\
\hline 56 & Ecolo & Belgium & -0.43 \\
\hline 57 & Flemish Interest & Belgium & -0.44 \\
\hline 58 & Progressive Party-PP & Brazil & -0.44 \\
\hline 59 & Northern League & Italy & -0.44 \\
\hline 60 & National Religious Party & Israel & -0.45 \\
\hline 61 & Socialist Party & Netherlands & -0.46 \\
\hline 62 & Democrat Humanist Centre & Belgium & -0.47 \\
\hline 63 & Fidesz - Hungarian Civic Alliance & Hungary & -0.49 \\
\hline 64 & New Democratic Party & Canada & -0.50 \\
\hline 65 & Conservative Party & United Kingdom & -0.50 \\
\hline 66 & Socialist Party & Chile & -0.51 \\
\hline 67 & Green Party & Sweden & -0.51 \\
\hline 68 & Independent Democratic Union & Chile & -0.52 \\
\hline 69 & National Action Party-PAN & Mexico & -0.52 \\
\hline 70 & Labour Party & Netherlands & -0.54 \\
\hline 71 & National Party & Australia & -0.55 \\
\hline 72 & $\begin{array}{c}\text { People's Party for Freedom and } \\
\text { Democracy }\end{array}$ & Netherlands & -0.55 \\
\hline 73 & Christian Democratic Appeal & Netherlands & -0.57 \\
\hline 74 & Liberal Alliance & Denmark & -0.58 \\
\hline 75 & Christian Democratic Party & Chile & -0.59 \\
\hline 76 & Liberal People's Party & Sweden & -0.60 \\
\hline 77 & Democratic Labour Party-PDT & Brazil & -0.63 \\
\hline 78 & Danish People's Party & Denmark & -0.63 \\
\hline 79 & Christian Social Union & Germany & -0.63 \\
\hline 80 & Christian Democrats & Sweden & -0.63 \\
\hline 81 & Democrats & Brazil & -0.64 \\
\hline 82 & Brazilian Labour Party-PTB & Brazil & -0.65 \\
\hline 83 & National Renewal & Chile & -0.70 \\
\hline 84 & Sinn Féin & Ireland & -0.72 \\
\hline 85 & Party for Democracy & Chile & -0.75 \\
\hline 86 & Socialist Party & Hungary & -0.78 \\
\hline 87 & Green & Belgium & -0.79 \\
\hline 88 & Christian Democratic Union & Czech Republic & -0.80 \\
\hline 89 & Free Democratic Party & Germany & -0.80 \\
\hline 90 & Alliance '90/The Greens & Germany & -0.81 \\
\hline 91 & Left Party & Sweden & -0.81 \\
\hline 92 & Social Liberal Party & Denmark & -0.86 \\
\hline
\end{tabular}




\begin{tabular}{|c|c|c|c|}
\hline 93 & Party of the Republic-PR & Brazil & -0.87 \\
\hline 94 & The Left & Germany & -0.89 \\
\hline 95 & Basque Nationalist Party & Spain & -0.90 \\
\hline 96 & National Regeneration Movement & Mexico & -0.91 \\
\hline 97 & Yisrael Beiteinu & Israel & -0.92 \\
\hline 98 & GreenLeft & Netherlands & -0.92 \\
\hline 99 & People's Party & Portugal & -0.92 \\
\hline 100 & Socialist Party-PSB & Brazil & -0.95 \\
\hline 101 & Democratic Left Alliance & Poland & -0.98 \\
\hline 102 & Democrats 66 & Netherlands & -0.99 \\
\hline 103 & Red-Green Alliance & Denmark & -1.00 \\
\hline 104 & Polish People's Party & Poland & -1.01 \\
\hline 105 & Union of the Centre & Italy & -1.04 \\
\hline 106 & Democratic Convergence of Catalonia & Spain & -1.05 \\
\hline 107 & ChristianUnion & Netherlands & -1.09 \\
\hline 108 & Civic Platform & Poland & -1.11 \\
\hline 109 & Liberal Democrats & United Kingdom & -1.13 \\
\hline 110 & TOP 09 & Czech Republic & -1.14 \\
\hline 111 & Jobbik & Hungary & -1.15 \\
\hline 112 & Reformed Political Party & Netherlands & -1.15 \\
\hline 113 & Left Bloc & Portugal & -1.15 \\
\hline 114 & United Left & Spain & -1.15 \\
\hline 115 & The Greens & Australia & -1.22 \\
\hline 116 & Bloc Québécois & Canada & -1.22 \\
\hline 117 & Law and Justice & Poland & -1.22 \\
\hline 118 & Meretz & Israel & -1.25 \\
\hline 119 & Italy of Values & Italy & -1.26 \\
\hline 120 & Republican Party-PRB & Brazil & -1.27 \\
\hline 121 & Green Party & Canada & -1.31 \\
\hline 122 & Scottish National Party & United Kingdom & -1.33 \\
\hline 123 & UK Independence Party & United Kingdom & -1.33 \\
\hline 124 & Party for the Animals & Netherlands & -1.34 \\
\hline 125 & Federalists, Democrats, Francophone & Belgium & -1.35 \\
\hline 126 & Politics Can Be Different & Hungary & -1.36 \\
\hline 127 & 50PLUS & Netherlands & -1.40 \\
\hline 128 & Ecologist Party 'The Greens' & Portugal & -1.41 \\
\hline 129 & Pirate Party & Germany & -1.43 \\
\hline 130 & Green Party & United Kingdom & -1.44 \\
\hline 131 & Plaid Cymru & United Kingdom & -1.45 \\
\hline 132 & Palikot's Movement & Poland & -1.47 \\
\hline
\end{tabular}

Sources: PPDB round 1a data (raw data, standardized and calculated by the authors) and official records for Latin American countries. 
Table C

Bivariate correlations, country level

\begin{tabular}{|l|c|c|c|c|c|c|c|}
\hline & HDI & $\begin{array}{c}\text { GDP per } \\
\text { capita }\end{array}$ & GDP & $\begin{array}{c}\text { Duration of } \\
\text { democracy }\end{array}$ & M/E & $\begin{array}{c}\text { Party } \\
\text { income }\end{array}$ & $\begin{array}{c}\text { PSI } \\
\text { (country } \\
\text { average) }\end{array}$ \\
\hline HDI & 1 & $0.905^{* * *}$ & 0.097 & $0.757^{* * *}$ & -0.311 & $0.526 * * *$ & 0.160 \\
\hline $\begin{array}{l}\text { GDP per } \\
\text { capita }\end{array}$ & $0.905^{* * *}$ & 1 & 0.012 & $0.818^{* * *}$ & -0.155 & 0.706 & $0.370^{*}$ \\
\hline GDP & 0.097 & 0.012 & 1 & 0.184 & -0.124 & 0.088 & -0.131 \\
\hline $\begin{array}{l}\text { Duration } \\
\text { of } \\
\text { democracy }\end{array}$ & $0.757 * * *$ & $0.818^{* * *}$ & 0.184 & 1 & -0.265 & $0.426 * * *$ & 0.123 \\
\hline M/E & -0.311 & -0.155 & -0.124 & -0.124 & 1 & 0.294 & $0.781^{* * *}$ \\
\hline $\begin{array}{l}\text { Party } \\
\text { Income }\end{array}$ & $0.526 * * *$ & $0.706 * * *$ & & $0.426 * * *$ & 0.294 & 1 & $0.827^{* * *}$ \\
\hline PSI & 0.160 & $0.370^{*}$ & -0.131 & 0.123 & $0.781^{* * *}$ & $0.827^{* * *}$ & 1 \\
\hline
\end{tabular}

Source: Calculated by the authors from PPDB round 1a data (raw data, standardized by the authors) and official records for Latin American countries.

$* \mathrm{p}<0.100 ; * * \mathrm{p}<0.05 ; * * * \mathrm{p}<0.01$.

Table D

Bivariate correlations, party level

\begin{tabular}{|l|c|c|c|c|c|c|c|c|c|}
\hline & HDI & $\begin{array}{c}\text { GDP per } \\
\text { capita }\end{array}$ & GDP & $\begin{array}{c}\text { Duration of } \\
\text { democracy }\end{array}$ & $\begin{array}{c}\text { Party } \\
\text { age }\end{array}$ & $\begin{array}{c}\text { Party } \\
\text { origin }\end{array}$ & M/E & $\begin{array}{c}\text { Party } \\
\text { income }\end{array}$ & PSI \\
\hline HDI & 1 & $0.910^{* * *}$ & 0.034 & $0.768^{* *}$ & $0.406 * * *$ & $0.264 * * *$ & $-0.176^{* *}$ & $0.333^{* *}$ & 0.095 \\
\hline $\begin{array}{l}\text { GDP per } \\
\text { capita }\end{array}$ & $0.910 * * *$ & 1 & -0.109 & $0.839 * * *$ & $0.482 * * *$ & $0.338^{* * *}$ & -0.106 & $0.451^{* * *}$ & $0.209 * *$ \\
\hline GDP & 0.034 & -0.109 & 1 & 0.021 & 0.108 & 0.053 & -0.058 & -0.131 & -0.114 \\
\hline $\begin{array}{l}\text { Duration of } \\
\text { democracy }\end{array}$ & $0.768 * *$ & $0.839 * * *$ & 0.021 & 1 & $0.441 * * *$ & $0.262 * * *$ & $-0.168 * *$ & $0.229 * *$ & 0.037 \\
\hline Party Age & $0.406 * * *$ & $0.482 * * *$ & 0.108 & $0.441^{* * *}$ & 1 & $0.762^{* * *}$ & 0.052 & $0.456 * *$ & $0.308^{* * *}$ \\
\hline Party Origin & 0.264 & $0.338^{* * *}$ & 0.053 & $0.262^{* * *}$ & $0.762^{* * *}$ & 1 & $0.183^{* *}$ & $0.451^{* * *}$ & $0.384 * * *$ \\
\hline M/E & $-0.176^{* *}$ & -0.106 & -0.058 & $-0.168^{* *}$ & 0.052 & $0.183^{* *}$ & 1 & $0.364 * * *$ & $0.826 * * *$ \\
\hline Party Income & $0.333^{* *}$ & $0.451^{* * *}$ & -0.131 & $0.1229 * *$ & $0.456 * * *$ & $0.451^{* * *}$ & $0.364 * * *$ & 1 & $0.826 * * *$ \\
\hline PSI & 0.095 & $0.209 * *$ & -0.114 & 0.037 & $0.308^{* * *}$ & $0.384 * * *$ & 0.826 & $0.826 * * *$ & 1 \\
\hline
\end{tabular}

Source: Calculated by the authors from PPDB round 1a data (raw data, standardized by the authors), and official records for Latin American countries.

$* \mathrm{p}<0.100 ; * * \mathrm{p}<0.05 ; * * * \mathrm{p}<0.01$.

\section{Resumo}

'Time after Time': força das organizações partidárias em democracias novas e antigas

O 'fator tempo' não tem sido sistematicamente considerado nos estudos comparados sobre organizações partidárias. A partir do mais completo banco de dados reunido até hoje sobre organizações partidárias, o Political Party Database Project (PPDB), o artigo testa o impacto do tempo, como variável de dois níveis (tempo de democracia e idade do partido), sobre a força organizacional dos partidos, em democracias novas e estabelecidas. Adicionamos dados originais de três países latino-americanos aos dezenove países cobertos pela primeira base de dados do PPDB (132 partidos ao todo). Os resultados sugerem que os partidos das democracias estabelecidas possuem menos filiados e mais dinheiro do que os das democracias mais recentes. Entre as novas democracias, a maior capacidade de mobilização de filiados produz partidos mais fortes na América Latina, quando comparada às democracias do Leste Europeu. Os achados desafiam a visão tradicional sobre a 
'fraqueza excepcional' dos partidos na América Latina e apontam para a importância do tempo como uma variável multinível: além do contexto nacional, a origem 'ancestral' do partido em regimes anteriores tem um grande impacto sobre a força organizacional dos partidos.

Palavras-chave: organizações partidárias; partidos políticos; filiação partidária; financiamento partidário; América Latina

\section{Resumen}

'Time after Time': fuerza organizativa de los partidos en democracias nuevas y antiguas

El "factor tiempo" no ha sido sistemáticamente considerado en los estudios comparados sobre organizaciones de partidos políticos. A partir de la base de datos más completa hasta la fecha sobre organizaciones partidistas, el Political Party Database Project (PPDB), en este artículo se pone a prueba el impacto del tiempo, como variable de dos niveles (tiempo de democracia y edad del partido), sobre la fuerza organizativa de los partidos en democracias nuevas y establecidas. Añadimos datos originales de tres países latinoamericanos a los diecinueve países cubiertos por la primera base de datos del PPDB (132 partidos en total). Los resultados sugieren que los partidos de las democracias establecidas poseen menos miembros y más dinero que los de las democracias recientes. Entre las nuevas democracias, la mayor capacidad de movilización hace los partidos más fuertes en América Latina que en la Europa Oriental. Los hallazgos desafían la visión tradicional sobre la excepcional debilidad de los partidos latinoamericanos y señalan la importancia del tiempo como variable multinivel: además del contexto nacional, el origen ancestral del partido en regímenes anteriores tiene un gran impacto sobre la robustez organizacional de los partidos.

Palabras clave: organizaciones partidistas; partidos políticos; membresía partidista; financiación de partidos; América Latina

\section{Résumé}

'Time after Time': la force organisationnelle des partis politiques dans les démocraties nouvelles et anciennes

Le "facteur temps" n'a pas été systématiquement pris en compte dans les études comparatives des organisations de partis. À partir de la base de données la plus complète sur le sujet, le Political Party Database Project (PPDB), l'article teste l'impact du temps en tant que variable à deux niveaux (durée de la démocratie et âge des partis) sur la force organisationnelle des partis dans les démocraties nouvelles et établies. Nous avons ajouté des données originales de trois pays d'Amérique latine aux dix-neuf pays couverts par la première base de données de PPDB (132 partis au total). Les résultats suggèrent que les partis des démocraties établies ont moins d'affiliés et plus d'argent que ceux des démocraties plus récentes. Parmi les nouvelles démocraties, la plus grande capacité de mobilisation produit des partis plus forts en Amérique latine, par rapport aux pays d'Europe de l'Est. Les résultats remettent en question la vision traditionnelle de la "faiblesse exceptionnelle" des partis d'Amérique latine et soulignent l'importance du temps en tant que variable multiniveau: outre le contexte national, l'origine "ancestrale" du parti dans les régimes précédents a un grand impact sur la force organisationnelle.

Mots-clés: organisations de partis; partis politiques; affiliés des partis politiques; financement de partis politiques; Amérique latine

Artigo submetido à publicação em 29 de junho de 2018. Versão final aprovada em 28 de janeiro de 2019.

Opinião Pública adota a licença Creative Commons CC-BY.

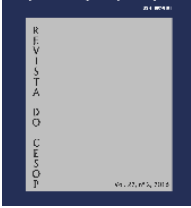

